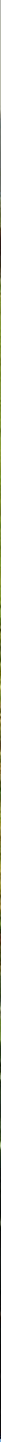

\title{
Typering extensieve landbouw in Nederland
}

Herman Agricola, Raymond Schrijver, Judith Westerink, Zoe van Eldik 



\section{Typering extensieve landbouw in Nederland}

Herman Agricola, Raymond Schrijver, Judith Westerink, Zoe van Eldik

Dit onderzoek is uitgevoerd door Wageningen Environmental Research en gesubsidieerd door het ministerie van Landbouw, Natuur en Voedselkwaliteit, in het kader van het Beleidsondersteunend onderzoekthema 'Biodiversiteit in de Kringlooplandbouw' (projectnummer BO-43-023.01-036).

Wageningen Environmental Research

Wageningen, februari 2021

Gereviewd door:

Bert Smit (Wageningen Economic Research)

Akkoord voor publicatie:

Joke de Jong, teamleider van Biodiversiteit en Beleid

Rapport 3062

ISSN 1566-7197 
Agricola, H.J., R.A.M. Schrijver, J. Westerink en Z.C.S. van Eldik, 2021. Typering extensieve landbouw in Nederland. Wageningen, Wageningen Environmental Research, Rapport 3062. 40 blz.; 11 fig.; 24 tab.; 21 ref.

Dit rapport brengt het aandeel extensieve landbouwbedrijven in beeld binnen de Nederlandse landbouw, evenals hun ruimtelijke spreiding. Daarvoor is een definitie ontwikkeld die samenhangt met de stikstofgebruiksnormen, om extensieve bedrijven in beeld te brengen die mogelijk goede condities scheppen voor biodiversiteit.

This report investigates the size of the extensive farming sector in the Netherlands, in terms of number of farms and in land managed. In addition, the spatial distribution of extensive farms is shown. Extensive farms were selected from the agricultural census data (2016) based on a definition related to norms for nitrogen application, in order to select farms that are likely to create favourable conditions for biodiversity.

Trefwoorden: natuurinclusieve landbouw, kringlooplandbouw, extensivering, stikstof, ruimtelijk

Dit rapport is gratis te downloaden van https://doi.org/10.18174/541710 of op www.wur.nl/environmental-research (ga naar 'Wageningen Environmental Research' in de grijze balk onderaan). Wageningen Environmental Research verstrekt geen gedrukte exemplaren van rapporten.

(C) 2021 Wageningen Environmental Research (instituut binnen de rechtspersoon Stichting Wageningen Research), Postbus 47, 6700 AA Wageningen, T 03174807 00, www.wur.nl/environmental-research. Wageningen Environmental Research is onderdeel van Wageningen University \& Research.

- Overname, verveelvoudiging of openbaarmaking van deze uitgave is toegestaan mits met duidelijke bronvermelding.

- Overname, verveelvoudiging of openbaarmaking is niet toegestaan voor commerciële doeleinden en/of geldelijk gewin.

- Overname, verveelvoudiging of openbaarmaking is niet toegestaan voor die gedeelten van deze uitgave waarvan duidelijk is dat de auteursrechten liggen bij derden en/of zijn voorbehouden.

Wageningen Environmental Research aanvaardt geen aansprakelijkheid voor eventuele schade voortvloeiend uit het gebruik van de resultaten van dit onderzoek of de toepassing van de adviezen.

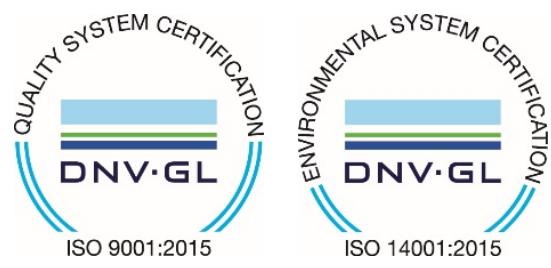

Wageningen Environmental Research werkt sinds 2003 met een ISO 9001 gecertificeerd kwaliteitsmanagementsysteem. In 2006 heeft Wageningen Environmental Research een milieuzorgsysteem geïmplementeerd, gecertificeerd volgens de norm ISO 14001.

Wageningen Environmental Research geeft via ISO 26000 invulling aan haar maatschappelijke verantwoordelijkheid.

Wageningen Environmental Research Rapport 3062 | ISSN 1566-7197

Foto omslag: Anton Stortelder 


\section{Inhoud}

Verantwoording $\quad 5$

$\begin{array}{ll}\text { Samenvatting } & 7\end{array}$

1

$\begin{array}{lr}\text { Inleiding } & 9\end{array}$

1.1 Aanleiding en onderzoeksvraag 9

$\begin{array}{lll}1.2 & \text { Aanpak en afbakening } & 10\end{array}$

2 Definitie van extensieve landbouw $\quad 12$

$2.1 \quad$ Eisen aan de definitie $\quad 12$

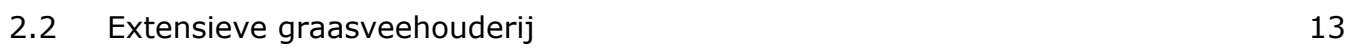

$\begin{array}{ll}2.3 & \text { Extensieve akkerbouw }\end{array}$

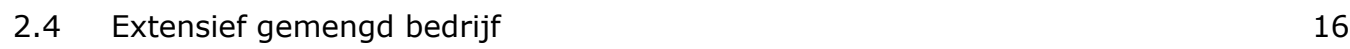

$\begin{array}{llr}3 & \text { Resultaten graasdierbedrijven } & 17\end{array}$

$\begin{array}{lll}3.1 & \text { Geselecteerde bedrijfstypen } & 17\end{array}$

$\begin{array}{lll}3.2 & \text { Verdeling intensiteit } & 17\end{array}$

3.3 Vergelijking extensieve bedrijven met gemiddelden $\quad 18$

$\begin{array}{lll}3.4 & \text { Ruimtelijke analyse } & 21\end{array}$

$4 \quad$ Resultaten akkerbouwbedrijven $\quad 23$

$4.1 \quad$ Geselecteerde bedrijfstypen $\quad 23$

$\begin{array}{lll}4.2 & \text { Verdeling intensiteit } & 24\end{array}$

4.3 Vergelijking extensieve bedrijven met gemiddelden $\quad 25$

$\begin{array}{lll}4.4 & \text { Ruimtelijke analyse } & 27\end{array}$

$5 \quad$ Resultaten gemengde bedrijven $\quad 29$

$\begin{array}{lll}5.1 & \text { Geselecteerde bedrijfstypen } & 29\end{array}$

$\begin{array}{lll}5.2 & \text { Verdeling intensiteit } & 29\end{array}$

5.3 Vergelijking extensieve bedrijven met gemiddelden 30

$\begin{array}{lll}5.4 & \text { Ruimtelijke analyse } & 31\end{array}$

$6 \quad$ Totaal extensieve bedrijven 33

$7 \quad$ Discussie en conclusies $\quad 35$

$\begin{array}{ll}\text { Literatuur } & 37\end{array}$

$\begin{array}{lll}\text { Bijlage } 1 & \text { Bedrijfstypen NSO-typering } & 38\end{array}$ 



\section{Verantwoording}

Rapport: 3062

Projectnummer: 5200046045

BAPS nummer: BO-43-023.01-036

Opdrachtgevers bij LNV: Laura van Rossem en Martijn van der Heide

De volgende deskundigen van WECR hebben meegedacht:

Marijke Dijkshoorn, Bert Smit, Ruud van der Meer

Wageningen Environmental Research (WENR) hecht grote waarde aan de kwaliteit van zijn eindproducten. Een review van de rapporten op wetenschappelijke kwaliteit door een referent maakt standaard onderdeel uit van ons kwaliteitsbeleid.

Referent die het rapport heeft beoordeeld:

functie: $\quad$ Senior onderzoeker Wageningen Economic Research

naam: $\quad$ Bert Smit

datum: $\quad 4$ januari 2021

Akkoord teamleider:

naam: Joke de Jong

datum: 1 februari 2021 


\section{Samenvatting}

Extensivering is een belangrijke route richting natuurinclusieve kringlooplandbouw. Dit rapport geeft inzicht in het huidige aandeel van extensieve bedrijven in de Nederlandse landbouw - zowel in de zin van het aantal bedrijven als het aandeel van het landbouwareaal dat zij beheren - en in verschillen tussen landbouwgebieden. Dit is verkend voor graasdierbedrijven (melkvee, overig rundvee en schapen), akkerbouwbedrijven en gemengde bedrijven met zowel veeteelt als akkerbouw. Er is alleen gekeken naar grondgebonden bedrijven, niet naar intensieve veehouderij- en glastuinbouwbedrijven. Op een aantal kenmerken, waaronder verdiencapaciteit, biologische landbouw en verbreding ${ }^{1}$, is een vergelijking gemaakt tussen extensieve bedrijven en de overige bedrijven in die sector.

Voor de analyse is gebruikgemaakt van de GIAB-database (Geografische Informatie Agrarische Bedrijven), waarmee ruimtelijke analyses kunnen worden gemaakt van de gegevens van de Landbouwtelling. De gebruikte gegevens zijn van 2016. Om bedrijven in GIAB als extensief te kunnen aanmerken, is gezocht naar indicatoren die kunnen worden afgeleid van parameters in GIAB en die een duidelijke relatie hebben met biodiversiteit. Gebruiksnormen voor stikstof zijn daarvoor een belangrijke sleutel. We hebben gekozen voor de volgende definities van extensieve landbouw:

- Graasdierbedrijven $\leq 1,5$ GVE-N/ha

- Akkerbouwbedrijven $\leq 150 \mathrm{~kg} \mathrm{~N} / \mathrm{ha}$ en $\geq 50 \%$ rustratio in het bouwplan

- Gemengde bedrijven $\leq 1,5 \mathrm{GVE}-\mathrm{N} / \mathrm{ha}$ en $\leq 150 \mathrm{~kg} \mathrm{~N} / \mathrm{ha}$ en $\geq 50 \%$ rustratio in het bouwplan

Op basis van deze definities is $19 \%$ van de Nederlandse graasdier-, akkerbouw- en gemengde bedrijven aan te merken als extensief. Dit betreft $25 \%$ van de graasdierbedrijven, $7 \%$ van de akkerbouwbedrijven en $5 \%$ van de gemengde bedrijven. Het relatief hoge aandeel extensieve graasdierbedrijven houdt verband met de overige rundvee- en schapenbedrijven. Deze zijn grotendeels extensief. Van de melkveebedrijven is $6 \%$ extensief. $12 \%$ van het Nederlandse landbouwareaal is in beheer bij extensieve bedrijven. Tussen landbouwgebieden in Nederland bestaan behoorlijke verschillen in het aandeel extensieve bedrijven. Dit houdt verband met landschap, bodemen bedrijfstype.

\footnotetext{
${ }_{1}$ Met verbreding wordt bedoeld het hebben van nevenactiviteiten op het bedrijf naast landbouw, in de vorm van recreatie, agrarisch natuurbeheer, boerderijeducatie, zorg, kinderopvang, verwerking van producten, verkoop van product en/of het aanbieden van ruimte voor de stalling van goederen.
} 


\section{$1 \quad$ Inleiding}

\subsection{Aanleiding en onderzoeksvraag}

Het ministerie van LNV ziet extensivering als belangrijke route richting natuurinclusieve landbouw. In algemene zin betekent extensivering van de landbouw minder inputs, minder emissies en (vaak) een lagere productie. Verwacht wordt dat minder inputs en minder emissies ruimte geven aan meer biodiversiteit. In het volgende hoofdstuk bakenen we af wat we in dit rapport bedoelen met extensief.

In een zoektocht naar handelingsperspectieven voor het stimuleren van extensivering is behoefte aan inzicht in de omvang en samenstelling van de extensieve sector en de verdeling over het land.

Onderzoeksvragen zijn:

1. Welk aandeel hebben extensieve bedrijven in het totaal van de Nederlandse landbouw?

2. Wat is de verspreiding van extensieve bedrijven over Nederland?

Dit onderzoek vormt een opmaat naar een groter onderzoek naar handelingsperspectieven gericht op extensivering, onder meer op basis van een analyse van verdienmodellen van extensieve landbouwbedrijven.

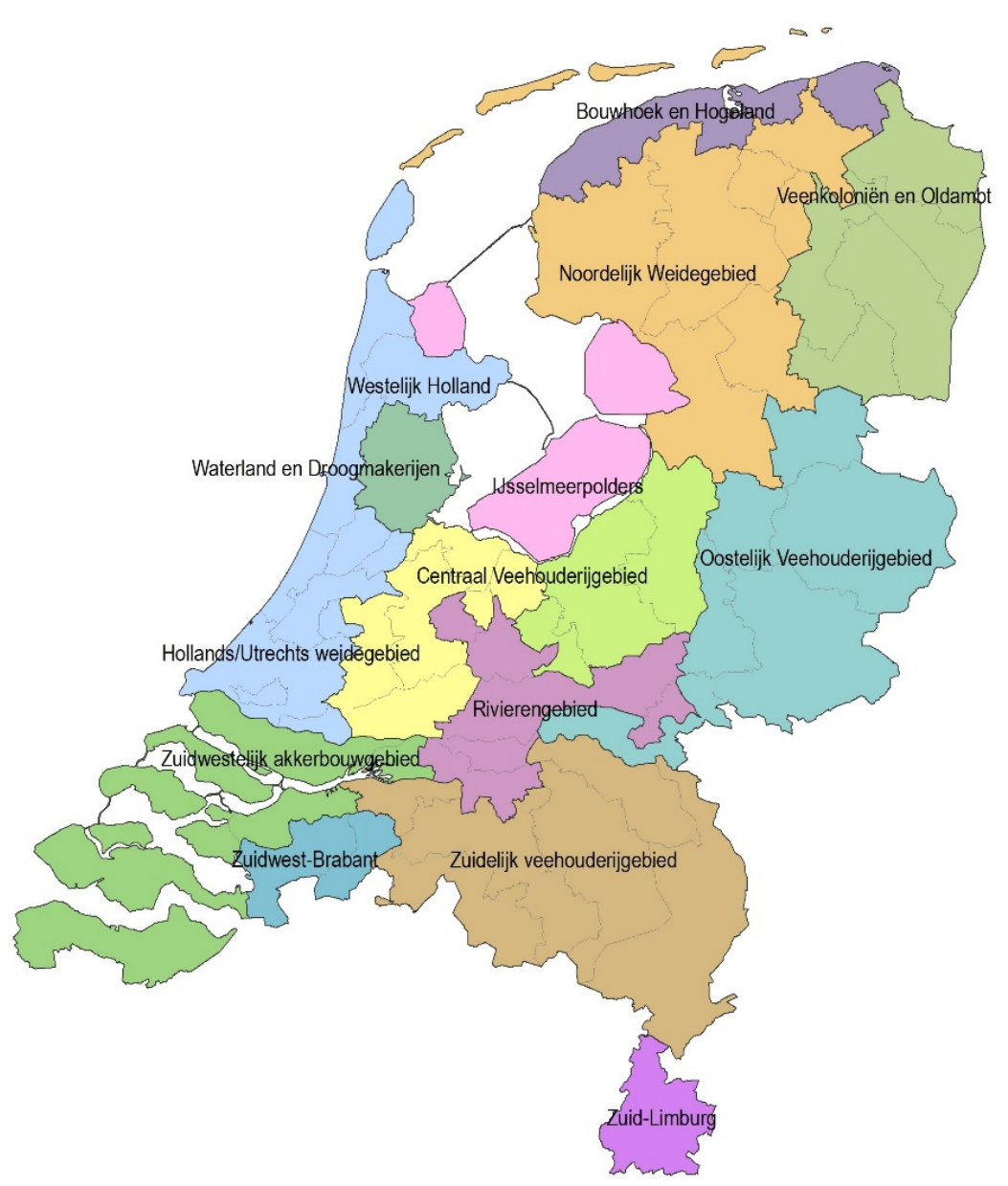

Figuur 1 Landbouwgebieden. 


\subsection{Aanpak en afbakening}

Om extensieve landbouw te kunnen kwantificeren, is een definitie nodig van het begrip 'extensief' voor verschillende landbouwsectoren. Voor de bepaling van deze definities zijn workshops gedaan binnen het projectteam en is aanvullend advies gevraagd aan andere deskundigen (zie Verantwoording). Zoals in het volgende hoofdstuk wordt toegelicht, moest voor het doel van dit onderzoek de definitie van extensieve landbouw samenhangen met de beschikbare indicatoren in de Landbouwtelling. De typologie in dit onderzoek is dus niet bedoeld als beleidscategorie, maar om de onderzoeksvraag te kunnen beantwoorden.

Voor de analyse is gebruikgemaakt van de GIAB-database (Geografische Informatie Agrarische Bedrijven). Deze bevat de gegevens van de Landbouwtelling en biedt de mogelijkheid om deze ruimtelijk inzichtelijk te maken. De Landbouwtelling is de grootste database van gegevens van landbouwbedrijven in Nederland. De gebruikte cijfers zijn van 2016. Voor de ruimtelijke analyse is de indeling gebruikt van landbouwgebieden in Nederland (Tabel 1).

Tabel 1 Indeling naar landbouwgebieden (CBS).

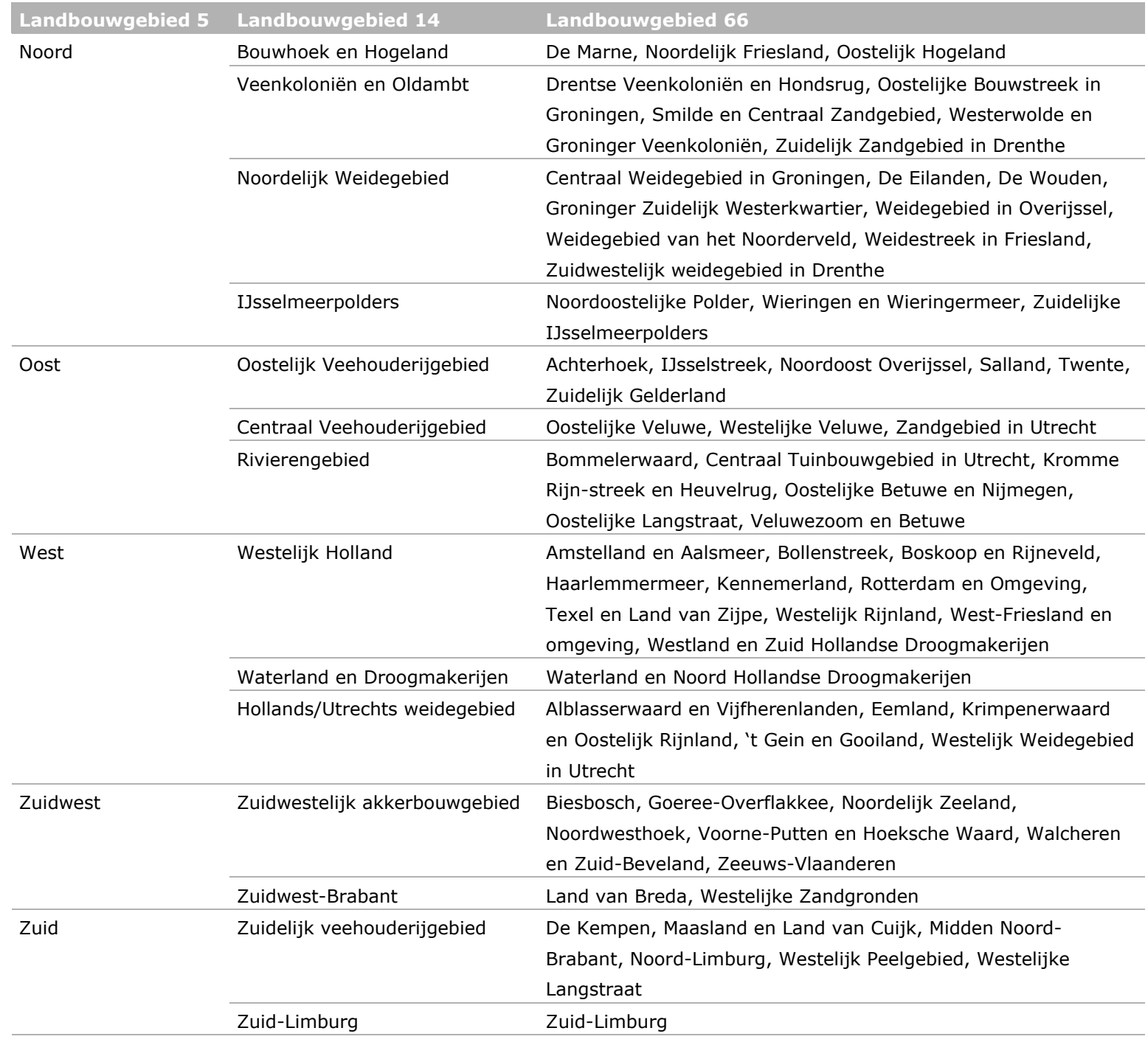

Uitgangspunt bij de definitie van extensieve landbouwbedrijven is dat het grondgebonden landbouwbedrijven betreft: het overgrote deel van het veevoer (met name ruwvoer) wordt geproduceerd op grond die in beheer is bij het betreffende bedrijf en de teelt van gewassen vindt plaats in de volle grond. Het gaat om akkerbouw-, veehouderij- of gemengde bedrijven met relatief 
extensief bouwland en/of een relatief lage veebezetting (zie hoofdstuk 2). We beperken ons in deze verkennende studie tot de bedrijfstypen in Tabel 2 volgens de NSO-typering (zie Bijlage 1).

Tabel 2 Geselecteerde bedrijfstypen analyse extensieve landbouwbedrijven.

\begin{tabular}{ll}
\hline Graasdierbedrijven & \\
\hline Type $=4500$ & Gespecialiseerde melkveebedrijven \\
\hline Type $=4612$ & Overige rundveebedrijven \\
\hline Type $=4810$ & Schapenbedrijven \\
\hline Akkerbouwbedrijven & \\
\hline Type $=1500$ & Graan-, oliezaad- en eiwitgewasbedrijven \\
\hline Type $=1601$ & Zetmeelaardappelbedrijven \\
\hline Type $=1602$ & Akkerbouwgroentebedrijven \\
\hline Type $=1603$ & Akkerbouwbedrijven met vooral voedergewassen \\
\hline Type $=1604$ & Overige akkerbouwbedrijven \\
\hline Type $=6100$ & Gewassencombinaties \\
\hline Gemengde bedrijven & \\
\hline Type $=8300$ & Akkerbouw/graasdiercombinaties \\
\hline Type $=8400$ & Overige gewas/veecombinaties \\
\hline
\end{tabular}




\section{Definitie van extensieve landbouw}

\subsection{Eisen aan de definitie}

De intensiteit van agrarische bedrijven wordt in de praktijk op diverse manieren uitgedrukt, afhankelijk van het doel van de classificatie en de beschikbaarheid van data. De intensiteit is doorgaans een maat voor de hoeveelheid van een bepaalde activiteit (een input of bewerking) per hectare of per arbeidskracht. Een bekende en veelgebruikte indeling op basis van standaard opbrengsten (SO) is een maat voor de economische omvang van bedrijven. Het legt een verband tussen de aantallen dieren en oppervlakte gewassen op een bedrijf en de daarmee te behalen omzet. Een hoge omzet vergt doorgaans ook hoge inputs. De hoeveelheid SO per hectare is daar een afspiegeling van. Deze omvat alle inputs, ook die van arbeid/activiteiten, waarvan de samenhang met biodiversiteit of milieubelasting niet zo duidelijk is. Veel handmatige arbeid heeft bijvoorbeeld eerder een negatief dan een positief effect op het energieverbruik: qua arbeid is het intensief, maar niet vanuit het oogpunt van energie-input. Mechanische onkruidbestrijding verbruikt meer energie en is arbeidsintensiever dan chemische onkruidbestrijding, maar chemische onkruidbestrijding heeft negatief effecten op biodiversiteit en milieu.

Zowel in het kader van het sluiten van kringlopen als voor de transitie naar een meer natuurinclusieve landbouw is er behoefte aan een definitie van extensieve landbouw die aansluit op de doelen die men met de transitie wil bereiken. Voor extensieve landbouw gaat dat voornamelijk om een lagere milieubelasting en een hogere biodiversiteit. Een definitie van intensiteit op basis van een brede economische indicator zoals de SO of de standaard verdiencapaciteit (SVC) is dan niet het meest geëigend voor het leggen van een relatie met biodiversiteit.

Het Louis Bolk instituut heeft een classificatie ontwikkeld op basis van bemesting, maairegime en beweiding op perceelniveau (Daniëls, 2014; Erisman et al., 2017), gebaseerd op een internationale studie van Allan et al. (2014). Hierin wordt een duidelijk verband gelegd tussen de intensiteit van de bedrijfsvoering en de biodiversiteit op melkveebedrijven. Voor een brede toepassing van de classificatie in ruimtelijke analyses en beleidsontwerpen hebben we dergelijke data het liefst voor de hele populatie landbouwbedrijven beschikbaar. GIAB biedt data aan op het gewenste populatieniveau, maar jammer genoeg niet in de mate van detail die voor bijvoorbeeld het classificatieschema van het LB gewenst is. In GIAB zijn geen gegevens over daadwerkelijke bemesting, beweidingsintensiteit en maairegimes opgenomen.

De twee belangrijkste eisen die we daarom hier aan de definitie voor extensieve landbouwbedrijven stellen, zijn:

a. Een voldoende samenhang tussen de indicator en te verwachten biodiversiteit en

b. Dat de betreffende indicator is opgenomen binnen GIAB of daaruit simpel is af te leiden.

In GIAB zijn wel de aantallen dieren en oppervlakten gewas in onderscheiden categorieën bekend. Deze kunnen in verband worden gebracht met de nutriëntenstromen die uiteindelijk de biodiversiteit beïnvloeden. Ook hierin zijn nog keuzes te maken. De basis voor het toekennen van gewichten aan afzonderlijke categorieën kan liggen bij diverse soorten (normatieve, dus niet de werkelijke) input van voer tot mest, of specifieke nutriënten zoals stikstof of fosfaat. Het ligt voor de hand om te kiezen voor stikstof en daarmee aan te sluiten bij het Nederlandse stikstofbeleid. Stikstof is medebepalend voor het wel of niet voorkomen van plantensoorten (Van Dobben, 2020) en is ook de meest beperkende factor voor landbouwkundige productie. Het effect van overmatig stikstofgebruik op natuurgebieden staat momenteel in een brede wetenschappelijke belangstelling. Het stikstofoverschot in de landbouw heeft onder andere via de route van ammoniakemissies een fors negatieve impact op een aantal natuurterreinen (Kros et al., 2008; Bobbink en Weijters, 2018). Een van de opties om het cumulatieve overschot terug te dringen, is door extensivering van veehouderijbedrijven. Hiermee kunnen puntbelastingen worden teruggedrongen mits de landbouwtechniek (vooral met betrekking tot 
het toedienen van nutriënten op het juiste tijdstip en het borgen van de bodemvruchtbaarheid) zelf niet verslechtert.

De vraag is vervolgens wat we als extensief kunnen classificeren. Voor graslanden geeft de veldgids van Schippers et al. (2012) goede handreikingen. Zij onderscheiden zes graslandfasen met een aflopende reeks van maximaal toelaatbare $\mathrm{N}$-giften en een min of meer oplopende reeks botanisch rijke en interessante graslanden. Voor akkers hebben Eichhorn en Van den Broek (2013) en op zandgrond Eichhorn en Ketelaar (2011) iets vergelijkbaars gedaan in opdracht van Natuurmonumenten.

In deze studie beperken wij ons tot een indicator op bedrijfsniveau ten bate van een analyse van landelijke cijfers. Van extensieve bedrijven is echter bekend dat zij (kunnen) werken met gradiënten in intensiteit van gebruik (Westerink et al., 2018). Om die gradiënten te kunnen beschrijven, is inzicht nodig in delen van bedrijven, zoals percelen. Wij stellen voor in dit onderzoek de stikstofexcretienormen voor dieren en gebruiksnormen voor gewassen te hanteren als basis voor de classificatie van intensiteit in de landbouw in relatie tot biodiversiteit. Dit biedt de mogelijkheid van een flexibele definitie van intensieve en extensieve bedrijven of van onderdelen van bedrijven, zoals percelen.

De keuze van een normatieve benadering betekent altijd dat er op individueel bedrijfsniveau afwijkingen zullen zijn tussen de normatieve (nutriënten)belasting en de werkelijke waarden in het veld. Gegeven de beschikbare data binnen GIAB is dat onvermijdelijk, maar het levert wel beperkingen of kanttekeningen op voor het gebruik van de typologie. Uiteindelijk is de grens tussen intensief en extensief per definitie een keuze (Westerink, 2016). De waarde van een classificatie ligt er echter ook in dat voor verschillende doeleinden (analyse, beleid) de klassegrenzen naar behoefte kunnen worden aangepast.

\subsection{Extensieve graasveehouderij}

Voor het bepalen van de intensiteit van veehouderijbedrijven kiezen wij voor het combineren van de stikstofexcretienormen voor dieren met het aantal dieren op het bedrijf. Om veehouderijbedrijven onderling te kunnen vergelijken, wordt het aantal dieren van verschillende diercategorieën vaak bij elkaar opgeteld tot zogeheten grootvee-eenheden (GVE). In de loop van de tijd zijn hiervan diverse lijsten ontstaan met een eigen basis voor de optelling. Het begrip GVE kent op deze manier meerdere definities, wat tot verwarring kan leiden. Zo werd voor het fosfaatreductieplan uit 2017 een op fosfaatexcretie gebaseerde norm voor runderen opgenomen (EZ, 2017). In het kader van het besluit algemene regels voor inrichtingen milieubeheer (VROM, 2009) werd de GVE gebaseerd op een levend gewicht van $500 \mathrm{~kg}$ en ook de EU hanteerde een eigen indeling in een verordening uit 2016 (EU, 2016).

Tabel 3 geeft een indruk van enkele bestaande indelingen en bevat tevens de op stikstofexcretie gebaseerde veenorm, de GVE-N zoals gebruikt in deze studie. Stikstofexcreties van verschillende diercategorieën zijn opgenomen in tabellen 4 en 6 van RVO (RVO, 2020a) en ook in de rapportage van het CBS over mest en mineralen uit 2019 (CBS, 2019), zie Tabel 4. Op basis van de excretienormen van het CBS en een enkele keer op basis van de rapportage in tabellen 4 en 6 RVO zijn voor deze studie nieuwe GVE-N-normen afgeleid (Tabel 3).

Bij het bepalen van de GVE-N zijn zo veel mogelijk de bestaande klasse-indelingen van bedrijven binnen GIAB gekoppeld aan beschikbare normen. ${ }^{2}$ De stikstofexcretie van een melkkoe met een productie van $8.870 \mathrm{~kg}$ en een ureumgetal van 23 is in Tabel 4 op 1 GVE-N gesteld. De GVE-N van alle andere diercategorieën zijn naar rato van hun overeenkomstige excretienormen geschaald.

\footnotetext{
2 In GIAB worden onder melk- en kalfkoeien ook zoogkoeien en mest- en weidekoeien gerekend. Hierdoor is het voor veel bedrijven lastig om deze groepen te onderscheiden (zie de eerste regel in Tabel 3). Het overgrote deel betreft echter gewoon melkkoeien, waardoor de fout hierdoor relatief klein is.
} 
Het voordeel van een GVE-N-norm is dat een relatie kan worden gelegd met de biodiversiteit van graslanden. Een niveau van stikstofexcretie waarbij het doel is dat de natuurwaarden op de landbouwpercelen toenemen, mag niet hoger zijn dan de stikstoftolerantie van het gewenste vegetatietype. Dat is het niveau waarbij het vegetatietype het in de concurrentie gaat afleggen tegen vegetatie met een hogere stikstoftolerantie, zoals de productieve graslandsoorten. Voor een productiegericht kruidenrijk grasland hoeft de huidige veebezetting niet per se omlaag. Voor het vestigen van vegetatietypen zoals die zijn omschreven in de veldgids van Schippers et al. (2012) is echter een daling van de veebezetting naar ongeveer één koe met bijbehorend jongvee per hectare het maximaal toelaatbare. Dat komt neer op maximaal 1,2 tot 1,5 GVE per ha. De bijbehorende stikstofexcretie van ongeveer $200 \mathrm{~kg}$ per ha is af te leiden uit Tabel 3 (dat is overigens voordat de gasvormige verliezen eraf worden getrokken die voor de berekening van de $170 \mathrm{~kg} \mathrm{~N}$-norm relevant zijn). Bij die hoeveelheid geeft de veldgids van Schippers et al. nog juist een grassen-mix (fase 1) aan als haalbaar. Voor een hoger doelbereik, bijvoorbeeld een gras-kruidenmix (fase 3), geldt al een veel lagere $\mathrm{N}$-gift, namelijk van maximaal $50 \mathrm{~kg} \mathrm{~N} / \mathrm{ha}$. Dat kan een bedrijf met gemiddeld 1,5 GVE/ha dus alleen bereiken op een deel van het land wanneer binnen het bedrijfssysteem gradiënten in bemestingsniveau worden aangebracht of wanneer mest wordt afgevoerd.

Op basis van bovenstaande kiezen wij voor het doel van deze studie voor de volgende definitie van extensieve veehouderijbedrijven: $\leq 1,5 \mathrm{GVE}-\mathrm{N} / \mathrm{ha}$.

Tabel 3 Overzicht van huidige GVE-normen in GIAB, EU-verordening, milieubeheer, fosfaatregeling en in deze studie gehanteerde GVE-N-norm.

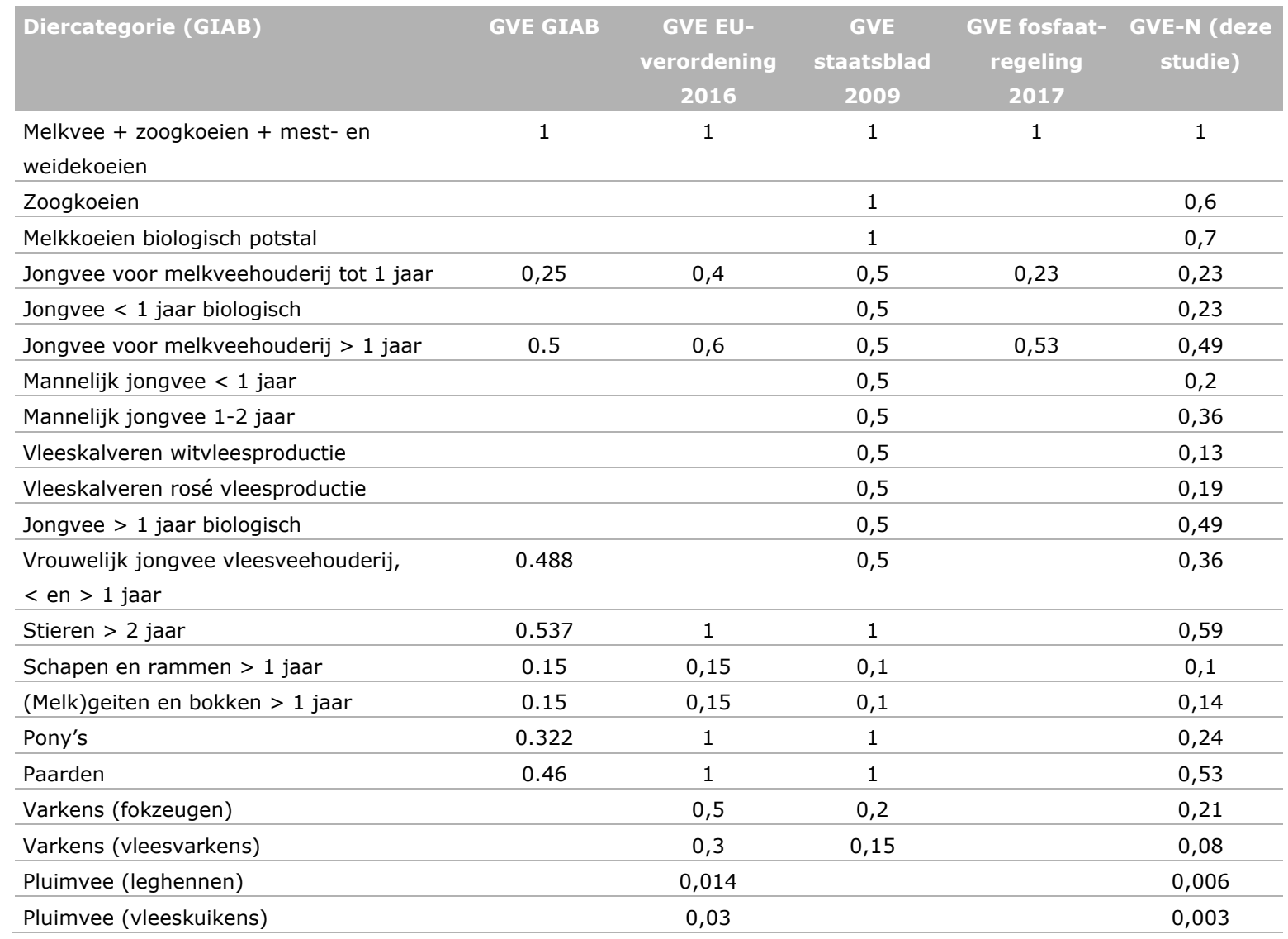


normen).

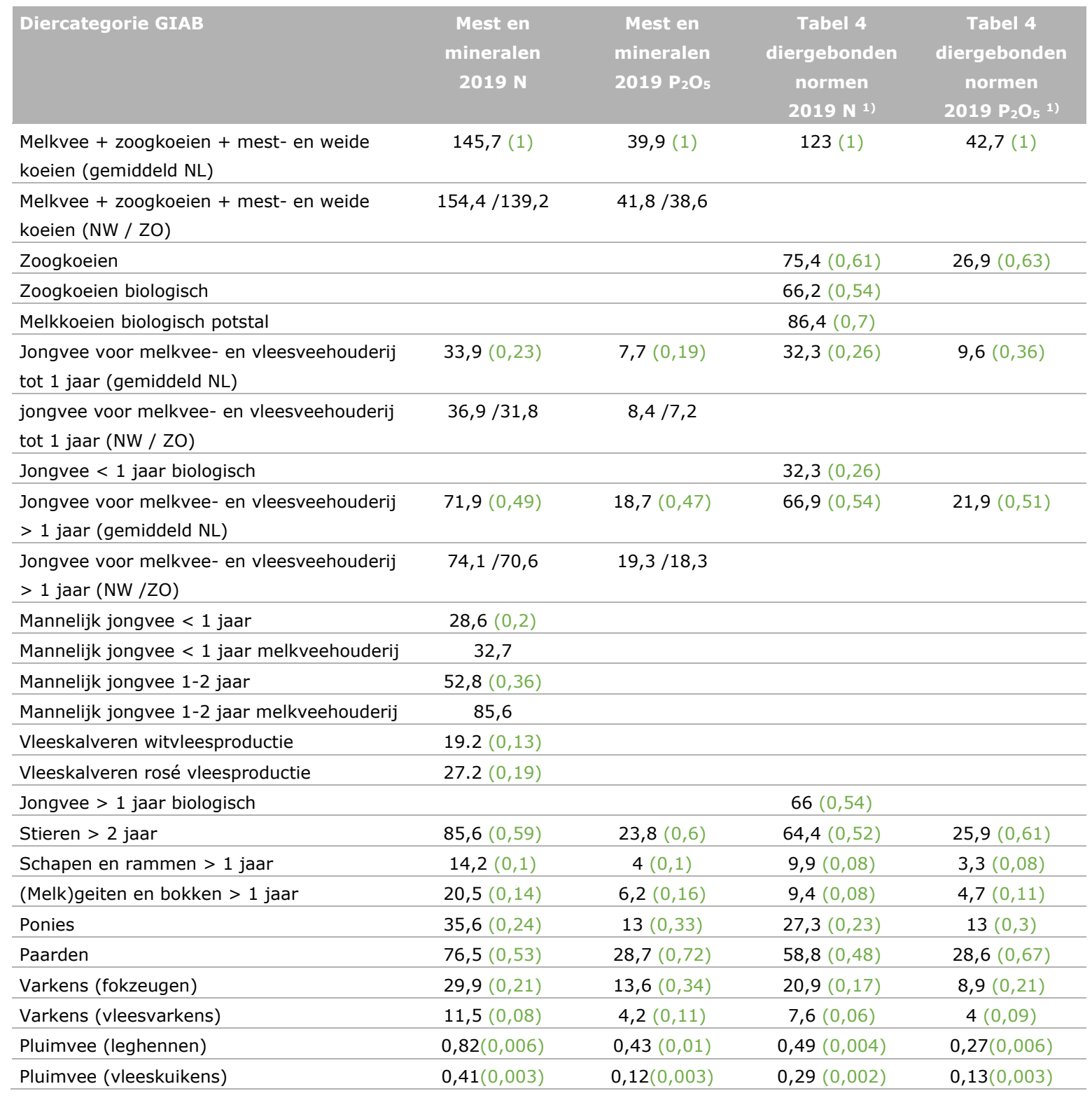

1) Bij $8.870 \mathrm{~kg}$ melkproductie (per koe per jaar) en een ureumgetal van 23.

\subsection{Extensieve akkerbouw}

In de akkerbouw wordt de intensiteit van het bouwplan (of teeltplan) meestal afgemeten aan het economische saldo dat met de gewassen te behalen is. In de KWIN-AGV (2018) is te zien dat met rooivruchten zoals aardappelen, suikerbieten en uien een hoger saldo valt te behalen dan met maaigewassen (of rustgewassen) zoals granen. Dat hogere saldo gaat vaak hand in hand met hogere inputs, bijvoorbeeld aan gewasbeschermingsmiddelen. $\mathrm{Er}$ is ook een relatie met het niveau van nutriënteninput. In de studies van Eichhorn en Ketelaar (2011) en Eichhorn en Van den Broek (2013) is een negatief verband aangetoond tussen de floristische kwaliteit (uitgedrukt in een kwaliteitsindex voor akkerflora, KIAF) en de hoeveelheid nutriënten die wordt toegediend. Evenals voor graslanden het geval is, wordt de hoogste floristische kwaliteit pas bereikt bij stikstoftoedieningen onder $50 \mathrm{~kg}$ $\mathrm{N} / \mathrm{ha}$ (en dan liefst in geoxideerde vorm: Bobbink en Weijters, 2018).

De GIAB-databank bevat geen data over de nutriënteninput op bedrijfsniveau, laat staan op perceelniveau. Gegevens over geteelde gewassen in het bouwplan zijn echter wel beschikbaar en via de wettelijk toelaatbare stikstofgebruiksnormen of N-normen (RVO 2020a, Tabel 2) kan een indruk 
worden verkregen van het stikstofgebruik per gewas wanneer op de norm wordt bemest (wat vermoedelijk veelal het geval zal zijn). De gebruiksnormen geven de ruimte aan die in totaal per gewas uit werkzame dierlijke mest (max. $170 \mathrm{~kg} \mathrm{~N} /$ ha zonder derogatie) en kunstmest samen op het land mag worden gebracht en zijn per gewas afhankelijk van de N-opnamecapaciteit (RVO 2020a, Tabel 2). De stikstofgebruiksnormen brengen op zichzelf echter slechts een beperkt onderscheid aan tussen de gewassen, omdat de $\mathrm{N}$-opname door een gewas ook binnen bijvoorbeeld de rooivruchten sterk verschilt.

Een ander criterium zou de bijdrage kunnen zijn van gewassen aan de organischestofbalans in de bodem. Gewassen die bekendstaan als rustgewas brengen meer effectieve organische stof (EOS) in de bodem, waardoor de balans tussen opbouw en afbraak eerder positief uitkomt. De efficiëntie waarmee gewassen stikstof opnemen en de verhoudingen waarin de opgenomen stikstof in eetbare versus nieteetbare plantorganen terechtkomt, speelt hierin ook een grote rol. Rooivruchten zoals aardappelen en suikerbieten, veel (blad)groenten en snijmais brengen veel minder EOS in de bodem dan rustgewassen, waardoor dit moet worden aangevuld met dierlijk mest en/of compost. Bij rooivruchten is de kans op uitspoeling van mineraal stikstof vaak groter (Van Dijk et al., 2012).

We hebben daarom de gewassenlijst van GIAB gecodeerd met de kenmerken stikstofgebruiksnorm ( $\mathrm{kg} \mathrm{N} / \mathrm{ha}$ ) en rustgewas (ja/nee). Hiermee kan per bedrijf de gemiddelde stikstofgebruiksnorm en het percentage rustgewas worden berekend die een maat zijn voor de intensiteit. Naar analogie van bij de dierlijke sector gekozen grenzen is de grens tussen intensief en extensief gekozen door de onderzoekers, in dit geval bij maximaal $150 \mathrm{~kg} \mathrm{~N} / \mathrm{Ha}$ en een rustratio in het bouwplan van $50 \%$. Voor een hoge bijdrage aan de floristische kwaliteit van de akkers zijn deze grenzen net zoals in de dierlijke sector nog veel te hoog. In de akkerbouw is het echter wel eenvoudiger dan in de veehouderij om ervoor te kiezen bepaalde percelen extensief te beheren door af te zien van bemesting of deze sterk te verminderen, omdat er geen mest wordt geproduceerd die geplaatst moet worden. Een akkerbouwer kan de totale stikstofgebruiksruimte van de gewasopgave naar eigen inzicht benutten. De keuze voor een aardappelras met een lagere $\mathrm{N}$-behoefte op een bepaald perceel schept dan bijvoorbeeld ruimte die op andere percelen kan worden benut. Het bemestingsplan kan zo worden afgestemd op een gewenste opbrengst of kwaliteit, of met het oog op extensief beheer van bepaalde percelen. Ook hier zal het in de praktijk dus gaan om gradiënten binnen het bedrijf.

Op basis van bovenstaande kiezen wij voor het doel van deze studie voor de volgende definitie van extensieve akkerbouwbedrijven: $\leq 150 \mathrm{~kg} \mathrm{~N} /$ ha en $\geq 50 \%$ rustratio in het bouwplan.

\subsection{Extensief gemengd bedrijf}

De definitie van een extensief gemengd bedrijf is nu simpelweg een optelling van de criteria die daaraan voor de extensieve graasveehouderij en extensieve akkerbouw zijn gesteld. Een gemengd bedrijf telt als extensief wanneer de GVE-N-norm lager is dan 1,5 en de bouwlandgewassen minder dan $150 \mathrm{~kg} \mathrm{~N} /$ ha ontvangen bij meer dan 50\% rustgewassen in het bouwplan. 


\section{Resultaten graasdierbedrijven}

\subsection{Geselecteerde bedrijfstypen}

Tot de grondgebonden graasdierbedrijven worden in dit onderzoek gerekend: melkveebedrijven, overige rundveebedrijven (bedrijven met hoofdzakelijk zoog- en weidevee) en schapenbedrijven (voor definitie en afbakening bedrijfstypen zie Bijlage 1 ). In totaal betreft het 23,5 duizend bedrijven met een totaal landbouwareaal van 1.037 duizend ha, respectievelijk $42 \%$ van de agrarische bedrijven in Nederland en $56 \%$ van het landbouwareaal. Deze graasdierbedrijven hebben in totaal 2.244 duizend GVE, $61 \%$ van het landelijk totaal. Het overige aandeel GVE valt vooral binnen de intensieve veehouderij, de sector die hier buiten beschouwing wordt gelaten. Onderstaande figuur geeft de verdeling van het aantal bedrijven, het landbouwareaal en het aantal GVE van de drie sectoren.

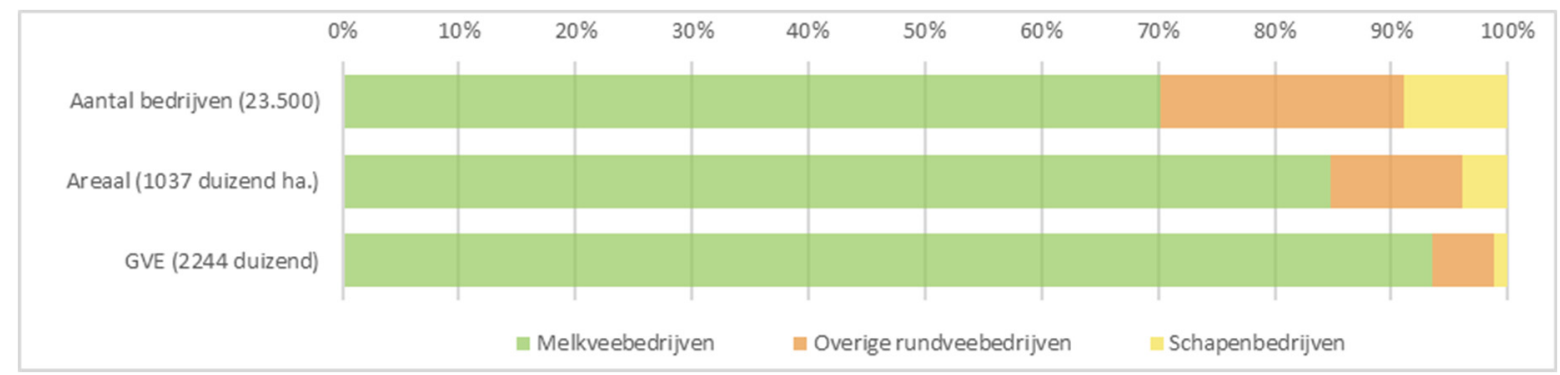

Figuur 2 Verdeling aantal bedrijven, landbouweareaal en GVE graasdierbedrijfstypen (GIAB 2016).

De melkveesector is in alle opzichten de belangrijkste graasdiersector. De overige rundvee- en schapenbedrijven hebben een betrekkelijk klein aandeel in het landelijk totaal van zowel het aantal bedrijven, het areaal en het aantal GVE. Figuur 2 laat totalen zien, ongeacht de veebezetting. In deze studie zijn we echter geïnteresseerd in de bedrijven met een veebezetting $\leq 1.5 \mathrm{GVE} / \mathrm{ha}$. De volgende paragraaf gaat daar verder op in.

\subsection{Verdeling intensiteit}

Figuur 3 geeft voor de graasdierbedrijfstypen de verdeling van het aantal bedrijven naar veedichtheid, waarbij het aandeel met een veedichtheid $\leq 1.5$ GVE donkerder gearceerd is.

Uit de frequentieverdeling blijkt dat slechts een klein deel van de melkveebedrijven als extensief is aan te duiden. Dit in tegenstelling tot de overige rundvee- en schapenbedrijven, waarvan juist het merendeel als extensief is te typeren. Tabel 5 geeft het overzicht van het aantal en aandeel extensieve bedrijven, GVE en areaal per bedrijfstype. Het aantal GVE is berekend op basis van de normen zoals aangegeven in hoofdstuk 2. 


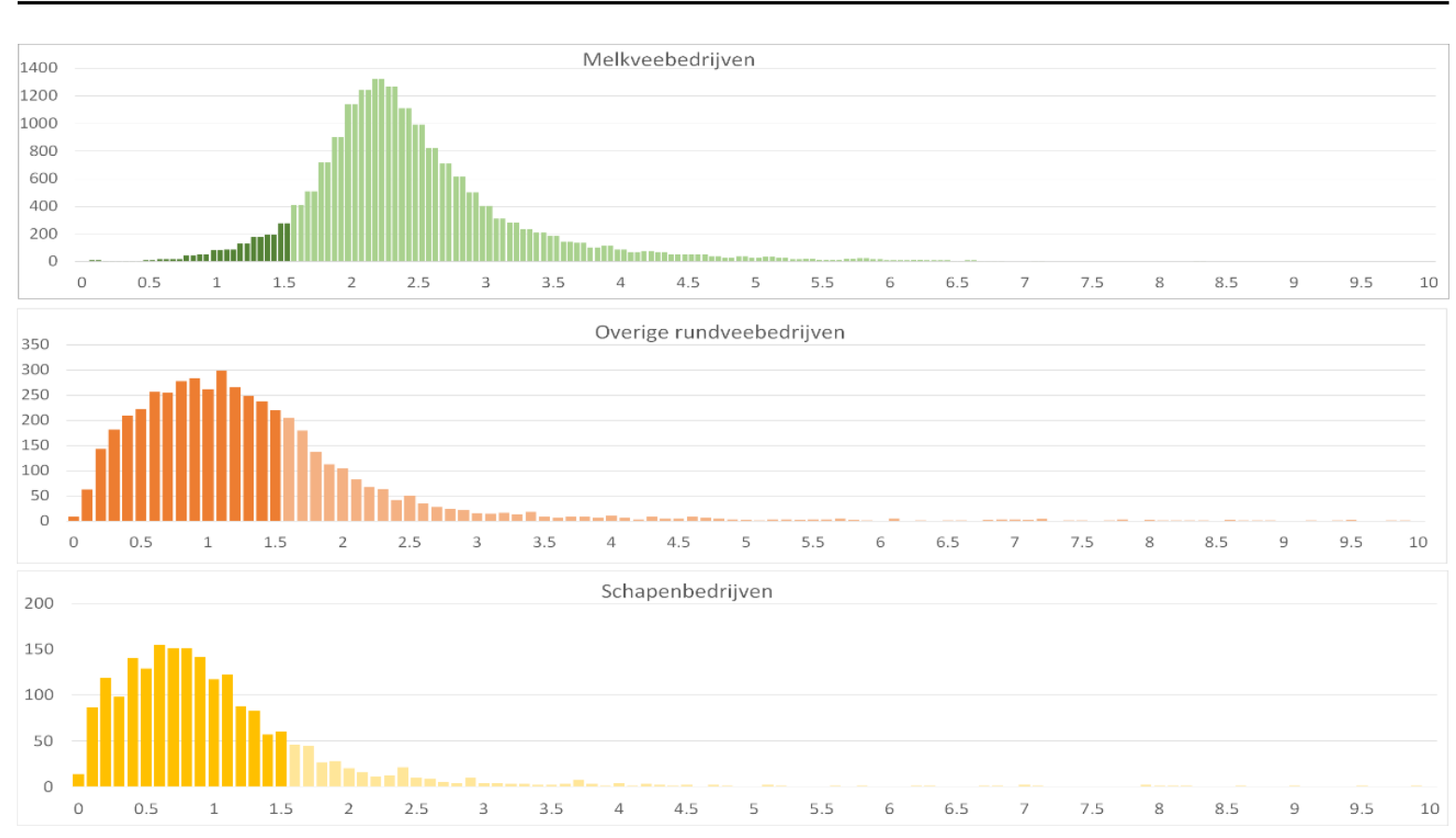

Figuur 3 Frequentieverdeling veedichtheid (GVE/ha) grondgebonden graasdierbedrijven (bron: GIAB 2016, bewerking WENR).

Tabel 5 Aantal en aandeel extensieve bedrijven, GVE en areaal graasdierbedrijven.

\begin{tabular}{|c|c|c|c|}
\hline & Extensieve bedrijven & Alle bedrijven & Aandeel extensief \\
\hline \multicolumn{4}{|l|}{ Aantal bedrijven (x 1.000) } \\
\hline Melkveebedrijven & 977 & 16.503 & $6 \%$ \\
\hline Overige rundveebedrijven & 3.334 & 4.910 & $68 \%$ \\
\hline Schapenbedrijven & 1.676 & 2.088 & $80 \%$ \\
\hline Totaal graasdierbedrijven & 5.987 & 23.501 & $25 \%$ \\
\hline \multicolumn{4}{|l|}{ Areaal (ha x 1.000) } \\
\hline Melkveebedrijven & 67 & 879 & $8 \%$ \\
\hline Overige rundveebedrijven & 94 & 118 & $80 \%$ \\
\hline Schapenbedrijven & 37 & 40 & $93 \%$ \\
\hline Totaal graasdierbedrijven & 198 & 1.037 & $19 \%$ \\
\hline \multicolumn{4}{|l|}{ GVE (x 1.000) } \\
\hline Melkveebedrijven & 76 & 2.099 & $4 \%$ \\
\hline Overige rundveebedrijven & 61 & 117 & $52 \%$ \\
\hline Schapenbedrijven & 20 & 28 & $71 \%$ \\
\hline Totaal graasdierbedrijven & 157 & 2.244 & $7 \%$ \\
\hline
\end{tabular}

(bron: GIAB 2016)

Absoluut gezien is de sector van de overige rundveebedrijven de grootste 'extensieve' sector met de meeste extensieve bedrijven en het grootste areaal. Qua aantal bedrijven komt daarna de schapenhouderijsector. Van de drie sectoren hebben de extensieve melkveebedrijven wel de meeste GVE. Slechts $6 \%$ van de melkveebedrijven heeft echter een veedichtheid $\leq 1.5 \mathrm{GVE} /$ ha en is op basis daarvan als extensief te typeren. Van de overige rundveebedrijven is dat $68 \%$ en van de schapenbedrijven zelfs $80 \%$.

\subsection{Vergelijking extensieve bedrijven met gemiddelden}

In deze paragraaf worden de bedrijfskenmerken van de extensieve graasdierbedrijven afgezet tegen die van de totale populatie van hetzelfde bedrijfstype. Daarvoor zijn de gemiddelde omvang en de intensiteit per bedrijf bepaald voor afzonderlijk de extensieve bedrijven en voor alle bedrijven van dat bedrijfstype samen. Verder is onderzocht of de extensieve bedrijven vaker biologisch en/of verbreed 
zijn en welk deel van het landbouwareaal dat ze in gebruik hebben, bestaat uit natuurlijk grasland en natuurterrein.

Tabel 6 geeft de gemiddelde verdiencapaciteit per bedrijf (op basis van de normatieve opbrengst) en de gemiddelde bedrijfsoppervlakte per bedrijfstype. De eerste kolom geeft het gemiddelde van de extensieve bedrijven en de tweede kolom het gemiddelde van alle bedrijven van het bedrijfstype. De derde kolom geeft het absolute verschil tussen het gemiddelde van de extensieve bedrijven en het gemiddelde van alle bedrijven. Het procentuele verschil in de laatste kolom is gerekend door het verschil te delen door het gemiddelde van alle bedrijven.

Tabel 6 Gemiddelde Verdiencapaciteit en bedrijfsgrootte graasdierbedrijven.

\begin{tabular}{|c|c|c|c|c|}
\hline & $\begin{array}{c}\text { Extensieve } \\
\text { bedrijven }\end{array}$ & Alle bedrijven & $\begin{array}{c}\text { Verschil } \\
\text { (absoluut) }\end{array}$ & Verschil ( $\%)$ \\
\hline \multicolumn{5}{|c|}{ Gem. VC/bedrijf ( $x \in 1.000)$} \\
\hline Overige rundveebedrijven & 9 & 11 & -2 & $-18 \%$ \\
\hline Schapenbedrijven & 2 & 2 & 0 & $0 \%$ \\
\hline Melkveebedrijven & 69 & 53 & +16 & $+30 \%$ \\
\hline Overige rundveebedrijven & 28 & 24 & +4 & $+17 \%$ \\
\hline Schapenbedrijven & 22 & 19 & +3 & $+16 \%$ \\
\hline
\end{tabular}

(bron: GIAB 2016)

Wat opvalt in de tabel is dat voor alle drie sectoren de extensieve bedrijven een gemiddelde verdiencapaciteit (VC/bedrijf) hebben die lager of gelijk is aan het populatiegemiddelde, terwijl het gemiddelde bedrijfsareaal (ha/bedrijf) ervan bij alle drie juist hoger is. Naast lagere verdiensten hebben ze dus hogere kosten voor grond. Tussen de bedrijfstypen zijn er grote verschillen. De melkveebedrijven zijn zowel qua VC als bedrijfsareaal gemiddeld veel groter dan de bedrijven van de andere sectoren. De lage VC/bedrijf van de overige rundvee- en schapenbedrijven betekent dat de meeste van deze bedrijven deeltijd of hobbymatig zijn, in ieder geval te klein om er een volwaardig inkomen uit te halen. Verder zien we dat de verschillen in de gemiddelden tussen de extensieve bedrijven en de totale populatie bij de melkveebedrijven veel groter zijn dan bij de andere sectoren, zeker in absolute cijfers.

Tabel 7 geeft de gemiddelde intensiteit van de graasdierbedrijven per bedrijfstypen uitgedrukt als de gemiddelde VC per ha en het gemiddeld aantal GVE per ha.

Tabel 7 Gemiddelde Verdiencapaciteit en veedichtheid (GVE) per ha op graasdierbedrijven.

\begin{tabular}{|c|c|c|c|c|}
\hline & $\begin{array}{c}\text { Extensieve } \\
\text { bedrijven }\end{array}$ & Alle bedrijven & $\begin{array}{c}\text { Verschil } \\
\text { (absoluut) }\end{array}$ & Verschil (\%) \\
\hline \multicolumn{5}{|l|}{ Gem. vc/ha (C) } \\
\hline Overige rundveebedrijven & 331 & 471 & -140 & $-30 \%$ \\
\hline Schapenbedrijven & 107 & 123 & -16 & $-13 \%$ \\
\hline Melkveebedrijven & 1,13 & 2,39 & -1.26 & $-53 \%$ \\
\hline Overige rundveebedrijven & 0,65 & 0,99 & -0.34 & $-34 \%$ \\
\hline Schapenbedrijven & 0,54 & 0,69 & -0.15 & $-22 \%$ \\
\hline
\end{tabular}

(bron: GIAB 2016)

Uit Tabel 7 blijkt dat de intensiteit van de productie van de melkveebedrijven veel hoger is dan van de andere bedrijfstypen. De gemiddelde VC/ha en GVE/ha van de melkveebedrijven is veel hoger en de verschillen tussen de extensieve bedrijven en de totale populatie zijn bij de melkveebedrijven ook veel 
groter dan bij de andere bedrijfstypen. De verschillen tussen de sectoren wat betreft de gemiddelde bedrijfsomvang en intensiteit van de productie zijn voor het grootste deel te verklaren door het verschil in frequentieverdeling van de intensiteit van de bedrijven zoals aangegeven in Figuur 3 . Ofwel de constatering dat de overige rundvee- en schapenbedrijven overwegend extensief zijn, terwijl van de melkveebedrijven slechts $6 \%$ als extensief is aan te merken.

Tabel 8 Biologische productie en verbrede landbouw graasdierbedrijven.

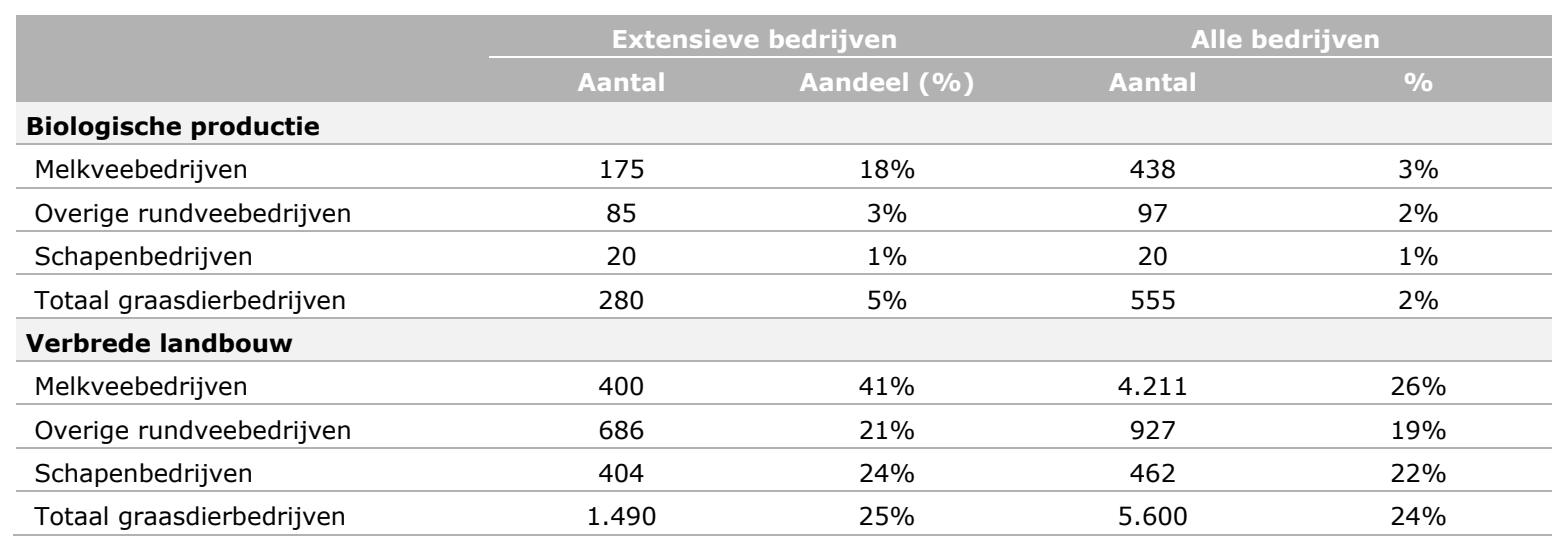

(bron: GIAB 2016)

De extensieve melkveebedrijven zijn relatief vaak biologisch (Tabel 8). Bij de andere bedrijfstypen is het verschil tussen de extensieve bedrijven en de totale populatie maar klein. Ook blijken de extensieve melkveebedrijven relatief vaker verbreed. Het gaat in dit verband vooral om agrarisch natuurbeheer, maar ook recreatie, educatie, verkoop en verwerking van producten en zorg komt bij de extensieve melkveebedrijven relatief meer voor. Voor de andere bedrijfstypen geldt ook hier dat het verschil in verbreding tussen de extensieve bedrijven en de totale populatie klein is.

Het Nederlandse landbouwareaal bedroeg in 2016 in totaal 1.867 duizend ha. Daarvan is ruim 90 duizend ha $(4,9 \%)$ natuurlijk grasland en bijna 30 duizend ha $(1,6 \%)$ natuurterrein, vooral begraasde heide. Volgens de systematiek van het CBS maken deze gronden deel uit van het landbouwareaal. De extensieve graasdierbedrijven blijken gezamenlijk 39 duizend ha natuurlijk grasland in gebruik te hebben (42\% van het totale areaal natuurlijk grasland) en 26 duizend ha natuurterrein ( $88 \%$ van het totale areaal natuurterrein dat meetelt als landbouwareaal).

Tabel 9 geeft de gemiddelde oppervlakte natuurlijk grasland en natuurterrein voor de graasdierbedrijfstypen en het aandeel van het bedrijfsareaal, eerst voor de extensieve bedrijven en daarna voor alle bedrijven van het betreffende bedrijfstype. De percentages in de tabel geven aan welk deel van de bedrijfsoppervlakte wordt bepaald door respectievelijk natuurlijk grasland en natuurterrein.

Tabel 9 Gem. oppervlakte (ha/bedrijf) natuurlijk grasland en natuurterrein graasdierbedrijven.

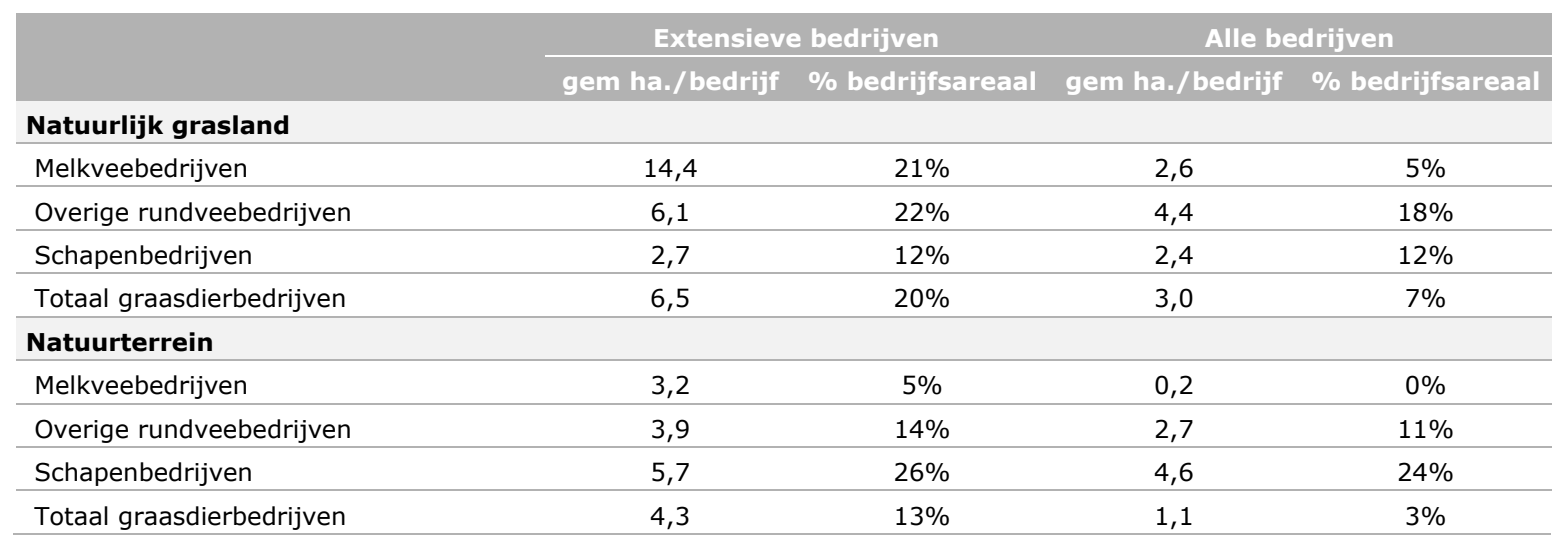

(bron: GIAB 2016) 
Extensieve melkveebedrijven beschikken gemiddeld over ruim 14 ha natuurlijk grasland, met een aandeel van $21 \%$ is dat meer dan een vijfde van de gemiddelde bedrijfsoppervlakte. Bij de overige rundveebedrijven hebben de extensieve bedrijven ongeveer eenzelfde aandeel natuurlijk grasland $(22 \%)$, bij de schapenbedrijven is dat lager (12\%). De schapenbedrijven hebben daarentegen gemiddeld het grootse areaal natuurterrein per bedrijf (met een aandeel van $26 \%$ van de gemiddelde bedrijfsoppervlakte). Niet heel verrassend, aangezien het vooral om heide gaat. Begrazing van natuurterrein vindt daarnaast plaats door zoogkoeien, zelden door melkvee.

\subsection{Ruimtelijke analyse}

Om een beeld te krijgen van de ruimtelijke verdeling van extensieve graasdierhouderij is per landbouwgebied het percentage extensieve graasdierbedrijven bepaald. Dat wil zeggen het aantal extensieve melkvee-, overige rundvee- en schapenbedrijven samen is afgezet tegen het totaalaantal bedrijven van deze drie bedrijfstypen. Daarnaast is het landbouwareaal bepaald dat in gebruik is bij de extensieve graasdierbedrijven. Er is voor gekozen om dit af te zetten tegen het totale landbouwareaal om zo per regio een indruk te krijgen welk deel van het totale landbouwareaal in gebruik is bij extensieve graasdierbedrijven. ${ }^{3}$

Landelijk blijkt 25\% van de graasdierbedrijven als extensief aan te duiden en deze bedrijven hebben $11 \%$ van het (totale) landbouwareaal in gebruik. Tabel 10 geeft het overzicht voor de indeling naar 5en 14-landbouwgebieden en de kaartjes (figuren 2 en 3) voor de indeling naar 66-gebieden.

Tabel 10 Ruimtelijke verdeling aantal en areaal extensieve graasdierbedrijven.

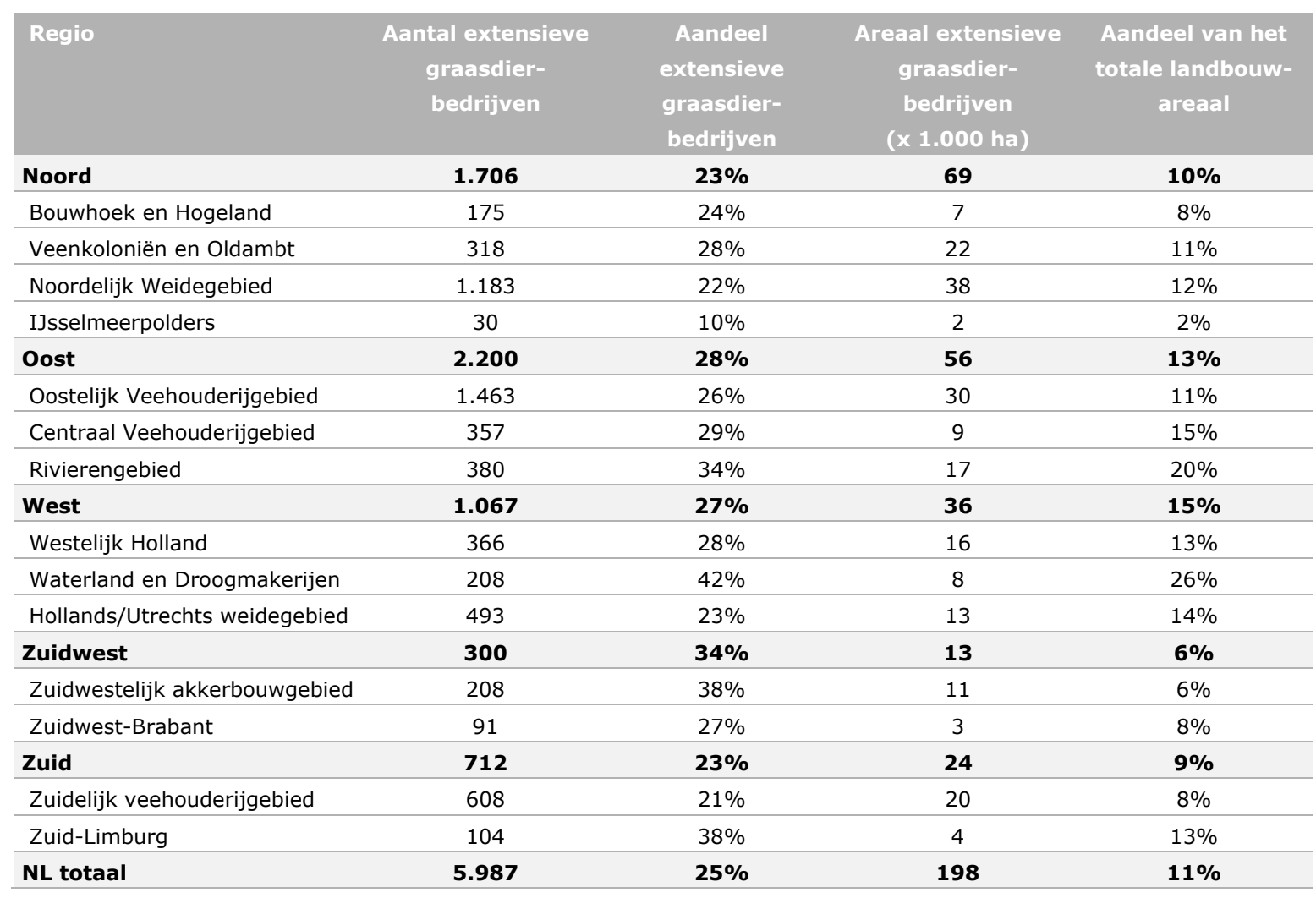

(bron: GIAB 2016)

Landelijk zijn bijna zesduizend graasdierbedrijven als extensief aan te duiden, dat is $25 \%$ van alle melkvee-, overige rundvee- en schapenbedrijven samen. Deze bedrijven hebben 198 duizend ha landbouwgrond in gebruik, ofwel 11\% van het Nederlandse landbouwareaal in 2016.

3 Door het uit te drukken als percentage van het areaal dat in gebruik is bij (alleen) graasdierbedrijven is eenzelfde verdeling te verwachten als bij de bedrijfsaantallen. 
Bij de indeling van vijf landbouwgebieden blijken West- en Oost-Nederland een bovengemiddeld aandeel extensieve bedrijven te hebben. Ook zien we dat in deze regio's het aandeel landbouwgrond dat in gebruik is bij extensieve graasdierbedrijven hoger is dan gemiddeld in Nederland. Voor Noorden Zuid-Nederland liggen deze aandelen juist onder het landelijk gemiddelde. Zuidwest-Nederland vormt een uitzondering: hoewel hier relatief veel extensieve graasdierbedrijven zijn, hebben deze maar een laag aandeel van de grond. De reden daarvoor is dat dit deelgebied (Zeeland en omgeving) een akkerbouwgebied is met maar weinig graasdierbedrijven.

Bij de indeling van 14-Landbouwgebieden komen Waterland en Droogmakerijen, Rivierengebied, Centraal Veehouderij gebied en Hollands/Utrechts weidegebied naar voren als de deelgebieden met het hoogste aandeel van de landbouwgrond in gebruik bij extensieve graasdierbedrijven. De IJsselmeerpolders en het Zuidwestelijk akkerbouwgebied hebben het laagste aandeel, dit zijn overwegend akkerbouwgebieden. Opvallend is dat het Zuidelijk veehouderijgebied ook een laag aandeel heeft. Onderstaande kaartjes (figuren 4 en 5 ) geven de uitsplitsing naar de 66 landbouwgebieden. Het blijkt dat gebieden in Midden-Nederland (het rivierengebied), WestNederland (Waterland en droogmakerijen) en Noord-Nederland (de Waddeneilanden) zowel een hoog aandeel extensieve graasdierbedrijven hebben als een hoog aandeel van het landbouwareaal dat in gebruik is bij deze bedrijven.

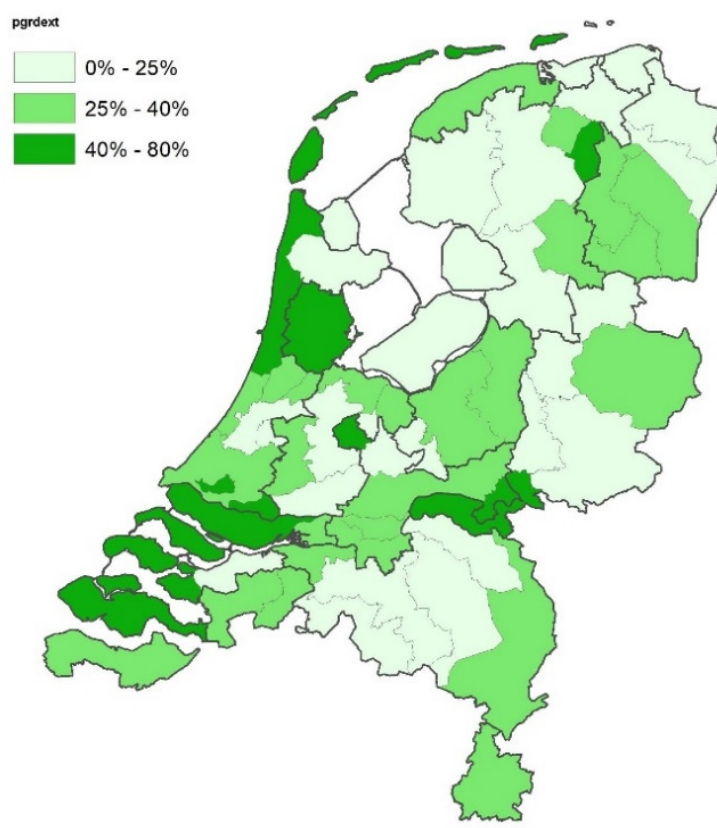

Figuur 4 Aandeel extensieve graasdierbedrijven in het totaal aantal graasbedrijven, per 66-regio (bron: GIAB 2016).

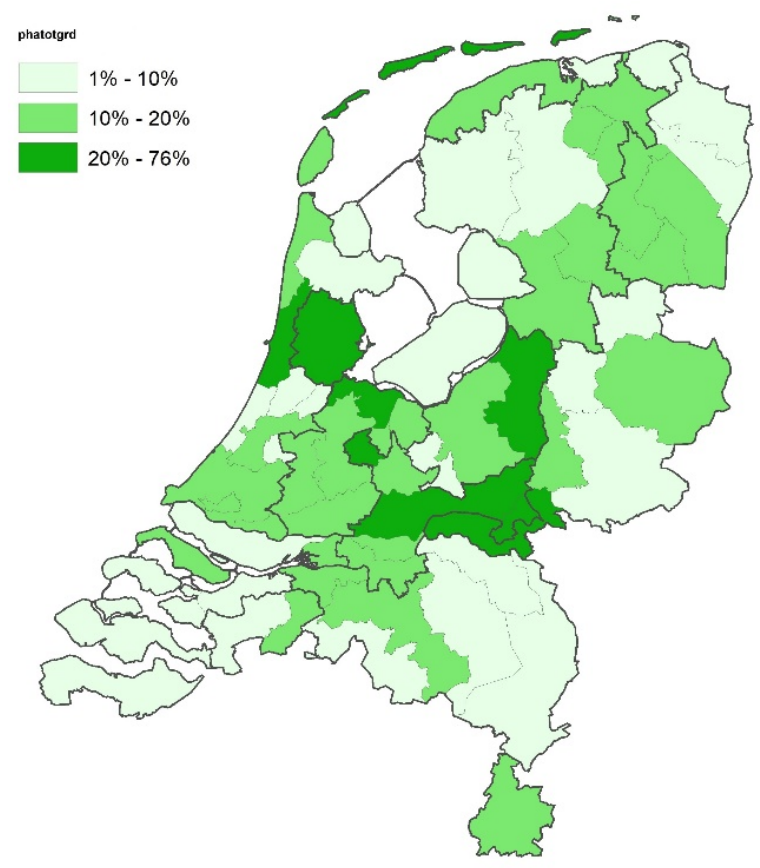

Figuur 5 Aandeel van het landbouwareal in gebruik bij extensieve graasdierbedrijven op het totale landbouwareaal (bron: GIAB 2016). 


\section{Resultaten akkerbouwbedrijven}

\subsection{Geselecteerde bedrijfstypen}

Nederland heeft volgens de NSO-typering (zie Bijlage 1) in 2017 bijna twaalfduizend akkerbouwbedrijven met een totaal landbouwareaal van bijna een half miljoen hectare, dat is respectievelijk $21 \%$ van het totaalaantal agrarische bedrijven en $27 \%$ van het landelijke landbouwareaal.

Op basis van de NSO-typering is voor de akkerbouwbedrijven een onderscheid te maken naar zes bedrijfstypen (zie Tabel 11). Omdat vruchtwisseling een belangrijk aspect is van akkerbouw, is er tussen de bedrijfstypen niet een duidelijk onderscheid in de gewassen die geteeld worden. Het bedrijfstype geeft aan welk type gewassen er binnen naar verhouding veel geteeld wordt. Voor het bedrijfstype 'Akkerbouwbedrijven met vooral voedergewassen' geldt bijvoorbeeld dat op ca. 95\% van het areaal voedergewassen wordt geteeld, vooral gras en snijmais. Het areaal van 'Graan-, oliezaaden eiwitgewasbedrijven' bestaat voor ca. $85 \%$ uit granen. Voor de overige bedrijfstypen zijn aardappelen, granen, suikerbieten en akkerbouwgroenten de belangrijkste gewassen. Van het totale landbouwareaal in gebruik bij de in Tabel 11 aangegeven akkerbouwbedrijven is ca. 25\% aardappelen, $25 \%$ granen, $15 \%$ suikerbieten, $10 \%$ akkerbouwgroenten en $5 \%$ overige akkerbouwgewassen. De resterende $20 \%$ bestaat uit grasland en groenvoedergewassen, vooral snijmais.

Tabel 11 Aantal, areaal, gem. rustratio en gem. N-norm per akkerbouwbedrijfstype. ${ }^{4}$

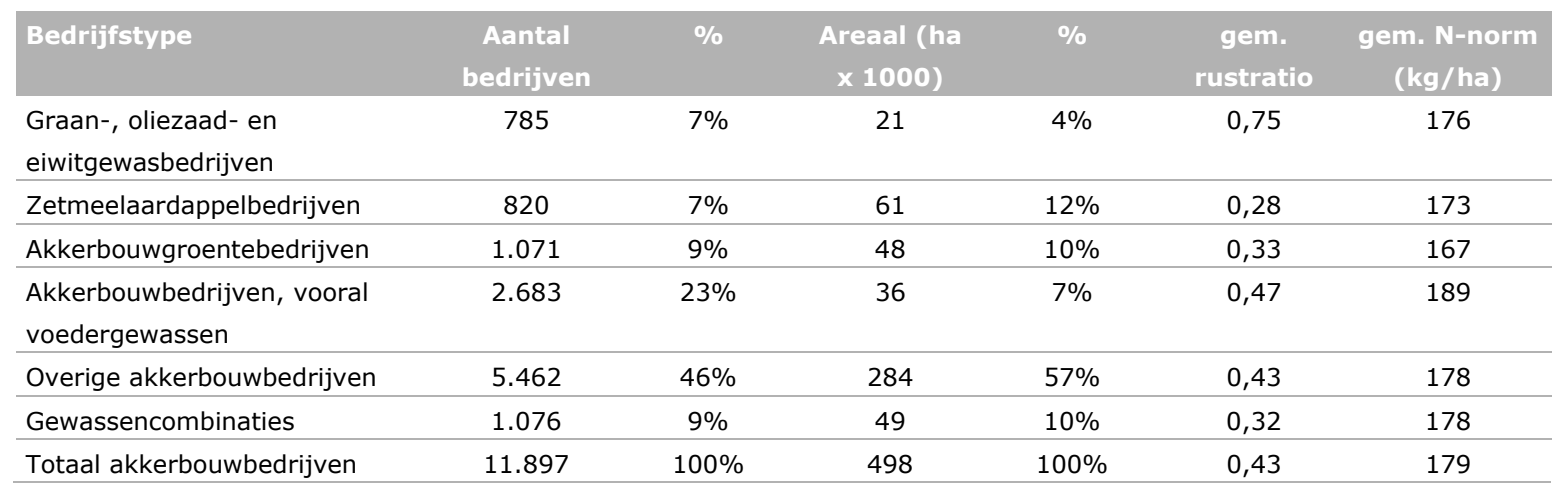

(bron: GIAB 2016)

Het bedrijfstype 'Overige akkerbouwbedrijven' is met bijna de helft van het aantal bedrijven en $57 \%$ van het areaal aan te duiden als het belangrijkste bedrijfstype binnen de akkerbouw. Dit bedrijfstype komt qua verdeling van de gewasarealen sterk overeen met het totaal van de akkerbouwbedrijven. Het betekent ook dat de gemiddelde rustratio en de N-norm voor dit bedrijfstype nagenoeg gelijk zijn aan die van de totale groep akkerbouwbedrijven.

Wat de rustratio betreft: we zien dat die relatief laag is (dus intensief) voor de Zetmeelaardappelbedrijven, Gewassencombinaties (met relatief veel tuinbouw) en Akkerbouwgroentebedrijven. De Graan-, oliezaad- en eiwitgewasbedrijven en Akkerbouwbedrijven (vooral voedergewassen) zijn op basis van de gemiddelde rustratio als relatief extensief aan te geven. De volgorde van de bedrijfstypen is wat betreft de rustratio zeer plausibel en biedt geen verrassing. De sectoren met relatief veel intensieve gewassen (aardappelen, bieten, uien, groente, tuinbouw) hebben een lage rustratio en de sectoren met veel rustgewassen (vooral graan, gras en vlinderbloemigen) hebben een gemiddeld hogere rustratio. De gemiddelde N-norm geeft een minder duidelijk beeld, omdat

\footnotetext{
4 Zie paragraaf 2.3 voor de onderbouwing van de indicatoren rustratio en $\mathrm{N}$-norm.
} 
de verschillen in de gemiddelde $\mathrm{N}$-norm tussen de bedrijfstypen klein zijn. De sectoren met veel intensieve gewassen blijken niet een hogere gemiddelde $\mathrm{N}$-norm te hebben.

\subsection{Verdeling intensiteit}

De intensiteit van akkerbouwbedrijven is in deze analyse bepaald op basis van de factoren rustratio en $\mathrm{N}$-norm per bedrijf. Extensieve akkerbouwbedrijven hebben in dit verband een hoge rustratio en een lage $\mathrm{N}$-norm. Onderstaande tabel geeft de frequentieverdeling van de akkerbouwbedrijven naar rustratio (verticaal) en $\mathrm{N}$-norm (horizontaal).

Tabel 12 Frequentieverdeling akkerbouwbedrijven naar rustratio en N-norm.

\begin{tabular}{lccccccc} 
& $<100 \mathrm{~N} / \mathrm{ha}$ & $100-125$ & $125-150$ & $150-200$ & $200-250$ & $>250 \mathrm{~N} / \mathrm{ha}$ & Total \\
Rustratio $<10 \%$ & 67 & 486 & 814 & 709 & 168 & 44 & 2.288 \\
\hline $10-30 \%$ & 58 & 184 & 462 & 1.308 & 264 & 14 & 2.290 \\
\hline $30-50 \%$ & 40 & 147 & 343 & 1.416 & 737 & 30 & 2.713 \\
\hline $50-70 \%$ & 28 & 131 & 208 & 811 & 767 & 62 & 2.007 \\
\hline $70-90 \%$ & 33 & 62 & 133 & 370 & 440 & 113 & 1.151 \\
\hline Rustratio $>90 \%$ & 80 & 50 & 89 & 226 & 285 & 718 & 1.448 \\
\hline Totaal & 306 & 1.060 & 2.049 & 4.840 & 2661 & 981 & 11.897 \\
\hline
\end{tabular}

(bron: GIAB 2016)

De meeste bedrijven vallen binnen de cellen met een $\mathrm{N}$-norm 150-200 kg N/ha en een rustratio tussen $0 \%$ en $50 \%$. Voor de extensieve bedrijven is bepaald dat de $\mathrm{N}$-norm maximaal 150 is en de rustratio minimaal $50 \%$. De groene cellen weerspiegelen op basis van deze premisse de extensieve akkerbouwbedrijven, een totaal van 841 bedrijven, $7 \%$ van het totaalaantal akkerbouwbedrijven. Tabel 13 geeft een overzicht van het aantal en het aandeel extensieve akkerbouwbedrijven per bedrijfstype en het areaal dat bij deze bedrijven in gebruik is.

Tabel 13 Aantal en aandeel extensieve bedrijven per akkerbouwbedrijfstype.

\begin{tabular}{|c|c|c|c|}
\hline & $\begin{array}{l}\text { Extensieve } \\
\text { bedrijven }\end{array}$ & Alle bedrijven & $\begin{array}{c}\text { Aandeel Extensief } \\
(\%)\end{array}$ \\
\hline \multicolumn{4}{|l|}{ Aantal bedrijven (x 1000) } \\
\hline Zetmeelaardappelbedrijven & 23 & 820 & $3 \%$ \\
\hline Akkerbouwgroentebedrijven & 65 & 1.071 & $6 \%$ \\
\hline Gewassencombinaties & 54 & 1.076 & $5 \%$ \\
\hline Totaal akkerbouwbedrijven & 814 & 11.897 & $7 \%$ \\
\hline \multicolumn{4}{|l|}{ Areaal (ha. $x$ 1000) } \\
\hline Graan-, oliezaad- en eiwitgewasbedrijven & 3,2 & 20,6 & $16 \%$ \\
\hline Overige akkerbouwbedrijven & 18,8 & 284,2 & $7 \%$ \\
\hline Gewassencombinaties & 1,7 & 49,2 & $4 \%$ \\
\hline Totaal akkerbouwbedrijven & 28,3 & 498,2 & $6 \%$ \\
\hline
\end{tabular}

(bron: GIAB 2016)

Het blijkt dat er binnen alle bedrijfstypen bedrijven zijn die voldoen aan de voorwaarde van een rustratio $>50 \%$ en een $\mathrm{N}$-norm $<150 \mathrm{~kg} \mathrm{~N} / \mathrm{ha}$. Het grootste deel van de extensieve akkerbouwbedrijven valt binnen de bedrijfstypen Graan-, oliezaad- en eiwitgewasbedrijven en Overige akkerbouwbedrijven. Dat geldt voor zowel het aantal bedrijven als voor het areaal; zowel absoluut als 
procentueel hebben deze bedrijfstypen het hoogste aandeel. Dat is ook niet vreemd gezien het aandeel rustgewassen dat zich per definitie op deze bedrijfstypen bevindt.

\subsection{Vergelijking extensieve bedrijven met gemiddelden}

In deze paragraaf worden de bedrijfskenmerken van de extensieve akkerbouwbedrijven afgezet tegen die van de totale populatie van het bedrijfstype. Achtereenvolgens komen aan de orde gemiddelde bedrijfsomvang, bedrijfsgrootte, rustratio, N-norm en het aandeel biologische en verbrede bedrijven.

Tabel 14 Gemiddelde Verdiencapaciteit en bedrijfsgrootte akkerbouwbedrijven.

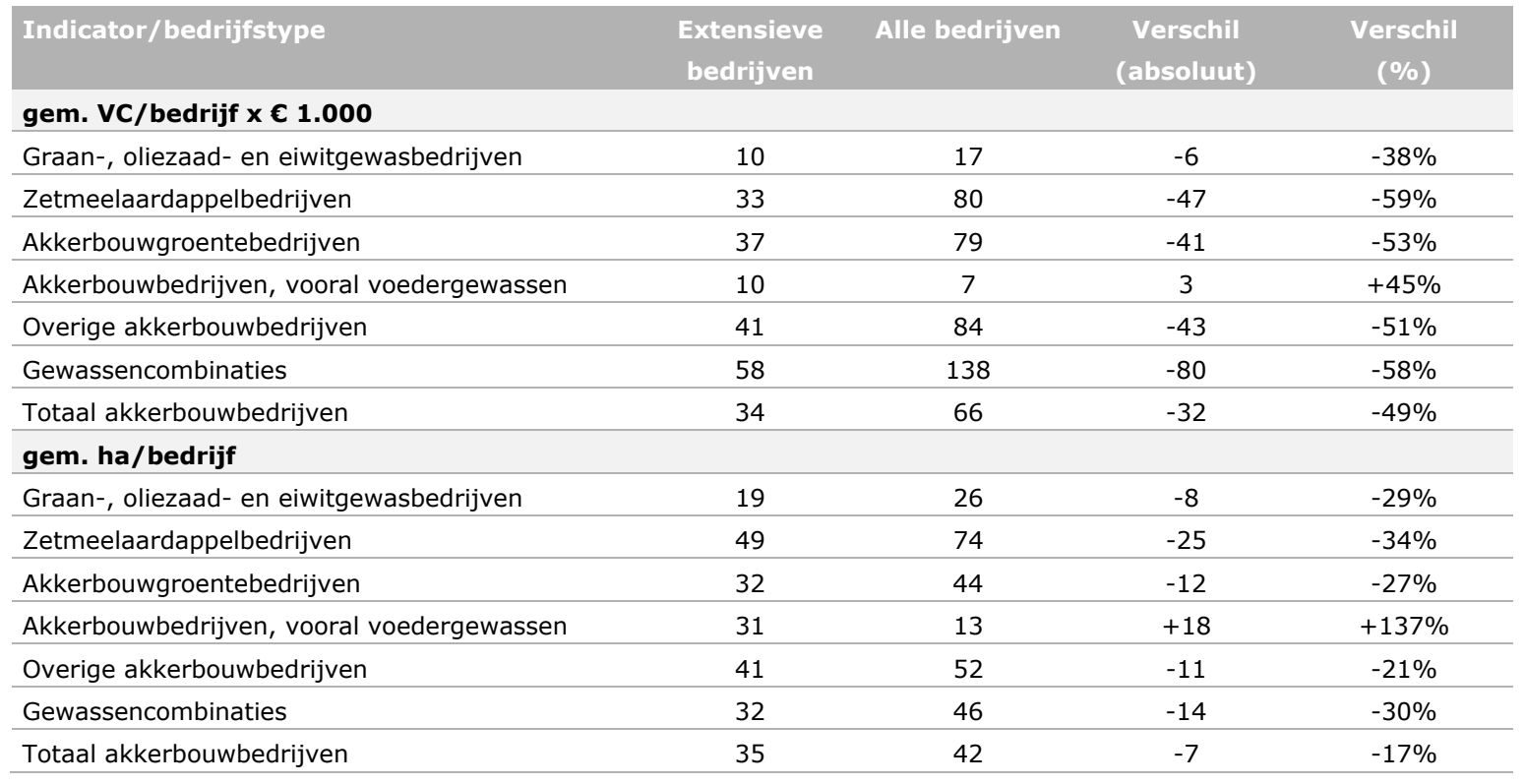

(bron: GIAB 2016)

De extensieve akkerbouwbedrijven als geheel zijn met een gemiddelde VC van $€ 33.000$ gemiddeld de helft kleiner dan de overige akkerbouwbedrijven. Ook het gemiddelde areaal van 35 ha is lager dan het totaalgemiddelde, al is het verschil minder groot $(-17 \%)$. Tussen de bedrijfstypen valt op dat de bedrijfstypen met een gemiddeld hoge rustratio (zie Tabel 13) in economische zin relatief kleine bedrijven zijn met een gemiddeld lage VC/bedrijf. Het grootste deel van deze bedrijven is hobbymatig/ deeltijd. De andere bedrijfstypen met een gemiddeld hogere VC per bedrijf hebben dus meer hoofdberoepsbedrijven en deze bedrijven zijn dus ook gemiddeld intensiever. Juist voor deze bedrijfstypen zien we ook dat de verschillen in bedrijfsomvang (VC) en -grootte (ha) tussen extensieve bedrijven en de totale populatie groter zijn. $\mathrm{Er}$ is dus een duidelijke relatie tussen intensiteit en bedrijfsomvang (VC): bedrijven met een grotere VC zijn doorgaans ook intensiever. 
Tabel 15 Gemiddelde rustratio en N-norm akkerbouwbedrijven.

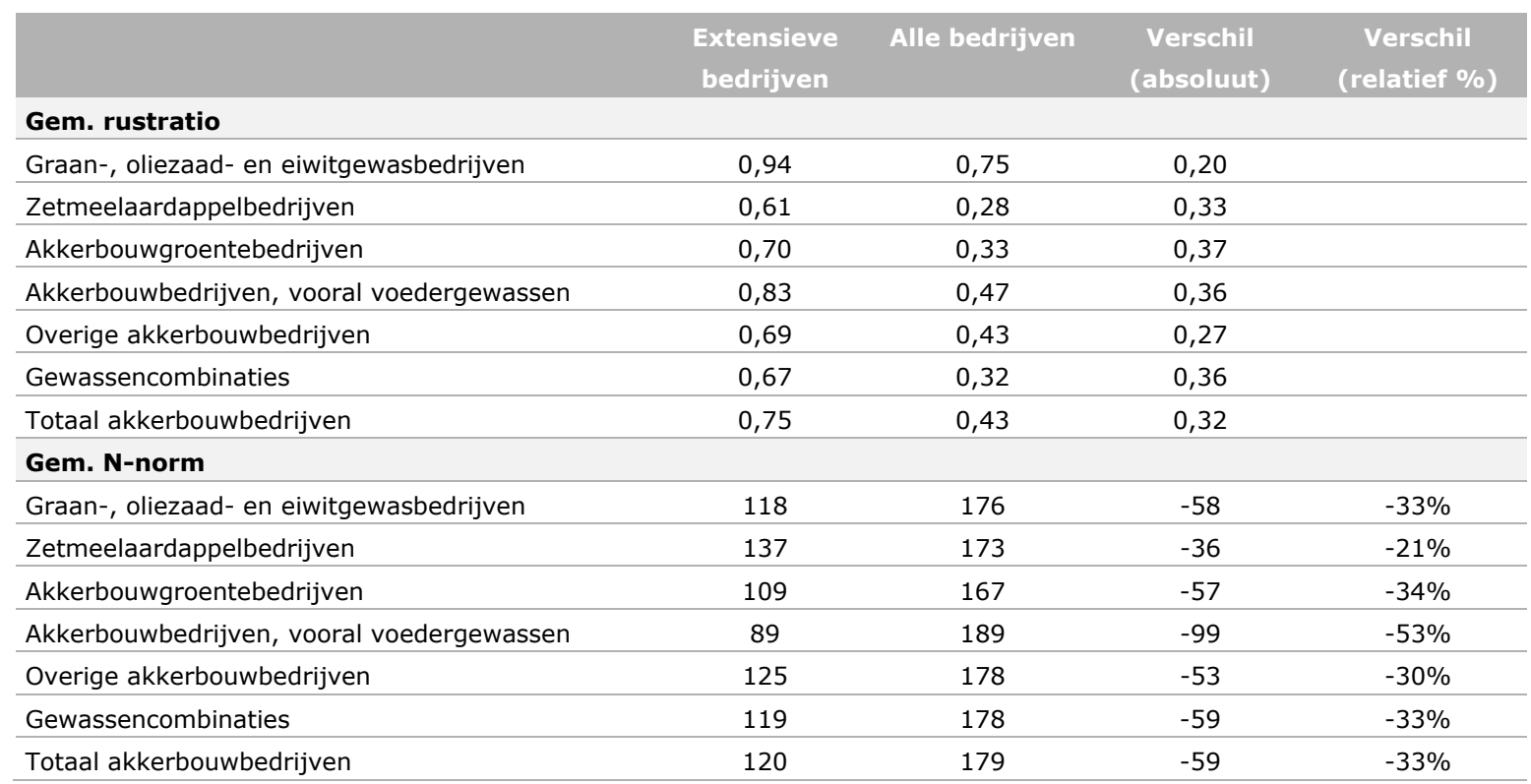

(bron: GIAB 2016)

Uit Tabel 15 komt naar voren dat de verschillen in rustratio en gemiddelde $\mathrm{N}$-norm tussen extensieve bedrijven en de totale populatie behoorlijk groot zijn. Op basis van deze indicatoren zijn de extensieve bedrijven gemiddeld ca. 20-50\% minder intensief dan het gemiddelde van de totale populatie.

Tabel 16 Biologische productie en verbrede landbouw op akkerbouwbedrijven.

\begin{tabular}{|c|c|c|c|c|}
\hline & \multicolumn{2}{|c|}{ Extensieve bedrijven } & \multicolumn{2}{|c|}{ Alle bedrijven } \\
\hline & Aantal & $\%$ & Aantal & $\%$ \\
\hline \multicolumn{5}{|l|}{ Biologische productie } \\
\hline Zetmeelaardappelbedrijven & 0 & $0 \%$ & 2 & $0 \%$ \\
\hline Akkerbouwgroentebedrijven & 2 & $3 \%$ & 88 & $8 \%$ \\
\hline Overige akkerbouwbedrijven & 14 & $3 \%$ & 61 & $1 \%$ \\
\hline Gewassencombinaties & 6 & $11 \%$ & 97 & $9 \%$ \\
\hline Totaal akkerbouwbedrijven & 37 & $5 \%$ & 306 & $3 \%$ \\
\hline \multicolumn{5}{|l|}{ Verbrede landbouw } \\
\hline Akkerbouwbedrijven, vooral voedergewassen & 5 & $12 \%$ & 358 & $13 \%$ \\
\hline Overige akkerbouwbedrijven & 99 & $22 \%$ & 920 & $17 \%$ \\
\hline Gewassencombinaties & 20 & $37 \%$ & 306 & $28 \%$ \\
\hline Totaal akkerbouwbedrijven & 157 & $19 \%$ & 1.911 & $16 \%$ \\
\hline
\end{tabular}

(bron: GIAB 2016)

Uit Tabel 16 blijkt dat over het geheel genomen de extensieve bedrijven vaker biologisch zijn. Ook zijn ze gemiddeld iets vaker verbreed. 


\subsection{Ruimtelijke analyse}

De ruimtelijke verdeling van het aantal akkerbouwbedrijven en het areaal dat ze in gebruik hebben, is weergegeven in de onderstaande tabel (Tabel 17). Het percentage extensieve akkerbouwbedrijven is uitgedrukt als aandeel van het totaalaantal akkerbouwbedrijven. Het aandeel van het landbouwareaal in gebruik bij de extensieve akkerbouwbedrijven is afgezet tegen het totale landbouwareaal. Dus $7 \%$ van de akkerbouwbedrijven in Nederland is als extensief aan te geven en deze bedrijven hebben 1,5\% van het (totale) landbouwareaal in gebruik.

Zowel het aantal als het aandeel extensieve akkerbouwbedrijven is laag in vergelijking met de graasdierbedrijven. Daar ging het om 5.987 bedrijven, $25 \%$ van de totale populatie en $11 \%$ van het landbouwareaal.

Bij de indeling naar vijf landbouwgebieden valt op dat alleen Zuid-Nederland een aandeel extensieve akkerbouwbedrijven heeft dat boven het landelijk gemiddelde ligt. Wat het areaal betreft, heeft Zuidwest-Nederland het hoogste aandeel, gevolgd door Zuid-Nederland. Absoluut gezien heeft NoordNederland overigens het grootste extensieve akkerbouwareaal. Oost- en West-Nederland hebben betrekkelijk weinig akkerbouwgrond en daardoor ook weinig extensieve akkerbouwbedrijven.

Bij de indeling naar 14-landbouwgebieden komt naar voren dat het hoge aandeel in Zuid-Nederland vooral wordt veroorzaakt door het hoge aandeel in Zuid-Limburg. Met 37\% extensieve akkerbouwbedrijven en $16 \%$ van het totale landbouwareaal heeft Zuid-Limburg verreweg het hoogste aandeel extensieve akkerbouw van alle 14 gebieden. Ook de deelgebieden Zuidwestelijk akkerbouwgebied en Zuidwest-Brabant hebben relatief veel extensieve akkerbouw, alsook de Veenkoloniën en het Oldambt in Noord-Nederland (figuren 6 en 7).

Tabel 17 Ruimtelijke verdeling aantal en areaal extensieve akkerbouwbedrijven.

\begin{tabular}{|c|c|c|c|c|}
\hline & $\begin{array}{l}\text { Aantal extensieve } \\
\text { akkerbouw- } \\
\text { bedrijven }\end{array}$ & $\begin{array}{c}\text { Aandeel in aantal } \\
\qquad(\%)\end{array}$ & $\begin{array}{l}\text { Areaal op } \\
\text { extensieve } \\
\text { akkerbouw- } \\
\text { bedrijven } \\
\text { (x } 1.000 \text { ha) }\end{array}$ & $\begin{array}{c}\text { Aandeel } \\
\text { van totale } \\
\text { landbouwareaal } \\
(\%)\end{array}$ \\
\hline Noord & 235 & $6 \%$ & 8.7 & $1,2 \%$ \\
\hline Veenkoloniën en Oldambt & 147 & $11 \%$ & 5.1 & $2,5 \%$ \\
\hline Noordelijk Weidegebied & 24 & $5 \%$ & 0.9 & $0,3 \%$ \\
\hline IJsselmeerpolders & 32 & $3 \%$ & 1.1 & $1,0 \%$ \\
\hline Oost & 63 & $3 \%$ & 2.4 & $0,6 \%$ \\
\hline West & 37 & $5 \%$ & 1.6 & $0,6 \%$ \\
\hline Westelijk Holland & 31 & $6 \%$ & 1.0 & $0,9 \%$ \\
\hline Waterland en Droogmakerijen & 1 & $1 \%$ & 0.1 & $0,1 \%$ \\
\hline Hollands/Utrechts weidegebied & 5 & $4 \%$ & 0.5 & $0,5 \%$ \\
\hline Zuidwest & 193 & $6 \%$ & 7.8 & $3,4 \%$ \\
\hline Zuidwestelijk akkerbouwgebied & 157 & $6 \%$ & 6.1 & $3,2 \%$ \\
\hline Zuidwest-Brabant & 35 & $11 \%$ & 1.7 & $4,9 \%$ \\
\hline Zuid & 283 & $12 \%$ & 7.7 & $2,9 \%$ \\
\hline Zuidelijk veehouderijgebied & 125 & $6 \%$ & 3.0 & $1,2 \%$ \\
\hline
\end{tabular}

(bron: GIAB 2016) 

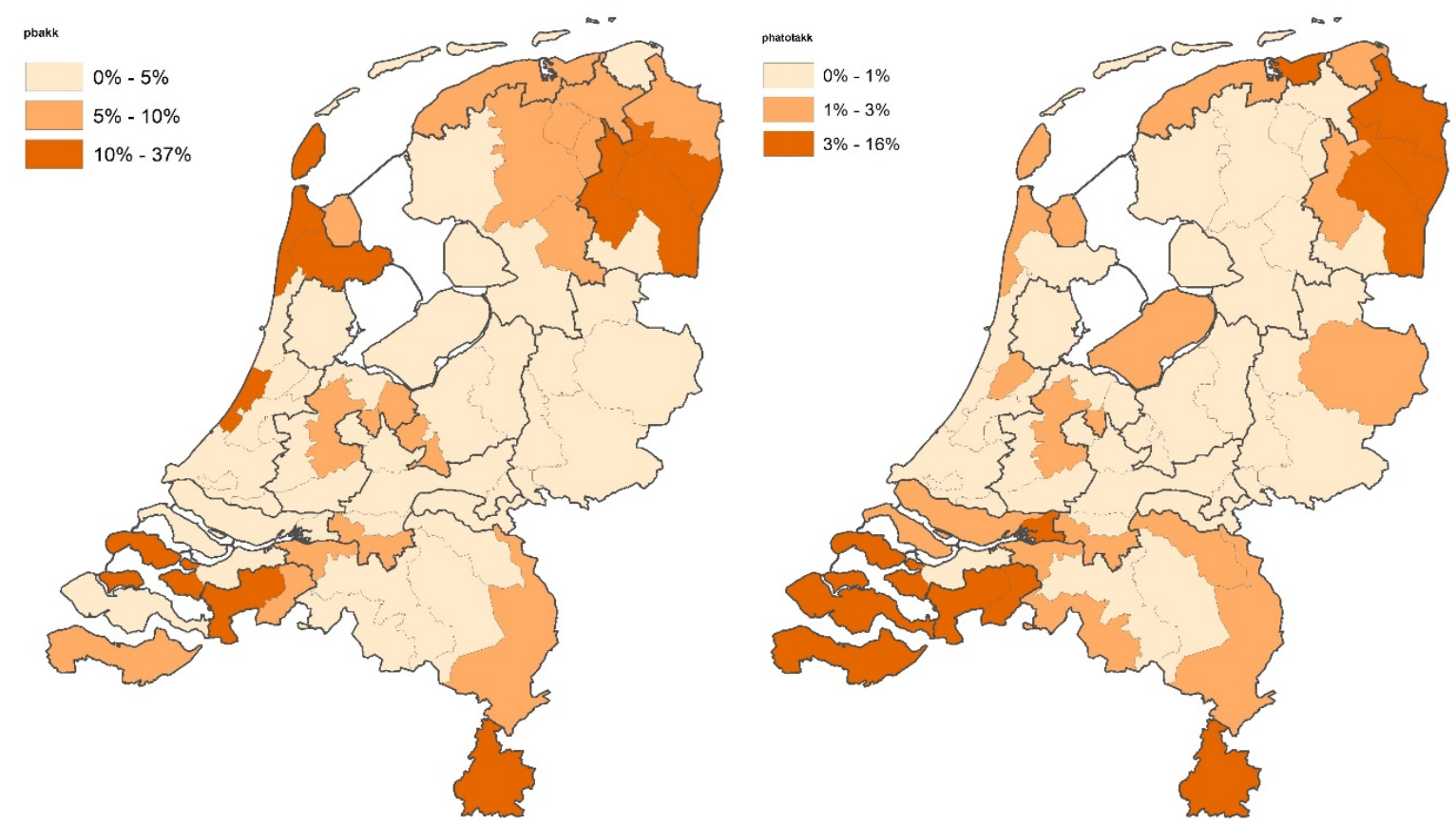

Figur 6 Aandeel extensieve

Figuur 7 Aandeel van het totale

akkerbouwbedrijven in het totaalaantal

landbouwareaal per gebied in gebruik bij

akkerbouwbedrijven per gebied (bron: GIAB 2016). extensieve akkerbouwbedrijven (bron: GIAB 2016). 


\section{Resultaten gemengde bedrijven}

\subsection{Geselecteerde bedrijfstypen}

Nederland heeft in totaal 1.429 gemengde bedrijven, dat zijn in deze studie bedrijven die veehouderij en akkerbouw combineren. Deze bedrijven hebben een landbouwareaal van in totaal 67 duizend ha, daarvan is $45 \%$ akkerbouw en $55 \%$ grasland en voedergewassen. In relatief opzicht is het aandeel van de gemengde bedrijven klein: slechts $3 \%$ van het totaalaantal agrarische bedrijven en $4 \%$ van het landbouwareaal. De gemengde bedrijven hebben op basis van de normen als aangegeven in hoofdstuk 2 in totaal 75 duizend GVE, dat is $2 \%$ van het landelijk totaal. Binnen de NSO-typering worden binnen de gemengde bedrijven twee bedrijfstypen onderscheiden: akkerbouw-graasdiercombinaties ( 760 bedrijven en 34 duizend ha) en overige gewas-veecombinaties ( 699 bedrijven met 33 duizend ha).

\subsection{Verdeling intensiteit}

Om te bepalen welk deel van de gemengde bedrijven als extensief is aan te geven, worden dezelfde criteria gehanteerd als bij de graasdier- en akkerbouwbedrijven: dat betekent $\leq 1.5 \mathrm{GVE} / \mathrm{ha}$ en rustratio $\geq 0.5$ en een $\mathrm{N}$-norm $\leq 150$. Tabel 18 geeft het aantal gemengde bedrijven volgens de afzonderlijke criteria en als de drie criteria samen worden genomen.

Tabel 18 Aantal en aandeel extensieve gemengde bedrijven voor drie criteria afzonderlijk en gezamenlijk.

\begin{tabular}{|c|c|c|}
\hline & Aantal bedrijven & Aandeel \\
\hline \multicolumn{3}{|l|}{ GVE/ha $\leq 1.5$} \\
\hline Akkerbouw-graasdiercombinaties & 718 & $94 \%$ \\
\hline Totaal gemengd bedrijf & 1.093 & $76 \%$ \\
\hline \multicolumn{3}{|l|}{ Rustratio $\geq 0.5$} \\
\hline Overige gewas-veecombinaties & 264 & $39 \%$ \\
\hline Totaal gemengd bedrijf & 611 & $43 \%$ \\
\hline \multicolumn{3}{|l|}{ N-norm $\leq 150$} \\
\hline Akkerbouw-graasdiercombinaties & 195 & $26 \%$ \\
\hline Akkerbouw-graasdiercombinaties & 49 & $6 \%$ \\
\hline Overige gewas-veecombinaties & 24 & $4 \%$ \\
\hline Totaal gemengd bedrijf & 73 & $5 \%$ \\
\hline
\end{tabular}

(bron: GIAB 2016)

Voor de afzonderlijke criteria blijkt dat relatief veel gemengde bedrijven voldoen aan de $1.5 \mathrm{GVE} / \mathrm{ha}$ norm, van de akkerbouw-graasdierbedrijven zelfs $94 \%$. De $\mathrm{N}$-norm $\leq 150$ blijkt het stringentst, slechts een kwart van de akkerbouw-graasdiercombinaties voldoet hier aan. Als alle drie criteria worden gesteld, blijkt dat $95 \%$ van de gemengde bedrijven hier niet aan kan voldoen. Slechts $6 \%$ van de akkerbouw-graasdierbedrijven en $4 \%$ van de overige gewas-veebedrijven voldoet er wel aan en is op basis daarvan als extensief te typeren. 
Tabel 19 Aantal extensieve gemengde bedrijven, areaal en aantal GVE.

Extensieve bedrijven Alle gemengde bedrijven Aandeel extensief ( $\%)$

\section{Aantal bedrijven}

\begin{tabular}{|c|c|c|c|}
\hline Akkerbouw-graasdiercombinaties & 49 & 760 & $6 \%$ \\
\hline Overige gewas-veecombinaties & 24 & 669 & $4 \%$ \\
\hline Totaal gemengd bedrijf & 73 & 1.429 & $5 \%$ \\
\hline Akkerbouw-graasdiercombinaties & 1.729 & 34.341 & $5 \%$ \\
\hline Overige gewas-veecombinaties & 1.131 & 32.832 & $3 \%$ \\
\hline \multicolumn{4}{|l|}{ GVE } \\
\hline Akkerbouw-graasdiercombinaties & 932 & 23.568 & $4 \%$ \\
\hline Overige gewas-veecombinaties & 754 & 51.611 & $1 \%$ \\
\hline Totaal gemengd bedrijf & 1.686 & 75.178 & $2 \%$ \\
\hline
\end{tabular}

(bron: GIAB 2016)

De in totaal 73 extensieve gemengde bedrijven hebben een landbouwareaal van 2.860 ha en 1.686 GVE. Duidelijk mag zijn dat dit een uiterst klein aandeel van de Nederlandse landbouw is: 2.860 ha staat gelijk aan $0,15 \%$ van het Nederlandse landbouwareaal.

\subsection{Vergelijking extensieve bedrijven met gemiddelden}

Tabel 20 Gemiddelde Verdiencapaciteit en bedrijfsgrootte gemengde bedrijven.

\begin{tabular}{|c|c|c|c|c|}
\hline & $\begin{array}{l}\text { Extensieve } \\
\text { bedrijven }\end{array}$ & Alle bedrijven & $\begin{array}{c}\text { Verschil } \\
\text { (absoluut) }\end{array}$ & Verschil $(\%)$ \\
\hline \multicolumn{5}{|l|}{ gem. vc/bedrijf $x \in 1.000$} \\
\hline Overige gewas-veecombinaties & 89 & 145 & -56 & $-39 \%$ \\
\hline Totaal gemengd bedrijf & 47 & 96 & -49 & $-51 \%$ \\
\hline Akkerbouw-graasdiercombinaties & 35 & 45 & -10 & $-22 \%$ \\
\hline Overige gewas-veecombinaties & 47 & 49 & -2 & $-4 \%$ \\
\hline Totaal gemengd bedrijf & 39 & 47 & -8 & $-17 \%$ \\
\hline
\end{tabular}

(bron: GIAB 2016)

De akkerbouw-graasdierbedrijven blijken gemiddeld een aanzienlijk lagere VC te hebben dan de overige gewas-veecombinaties (Tabel 20). Dit geldt nog sterker voor de extensieve akkerbouwgraasdiercombinaties. Opvallend is dat de verschillen in bedrijfsoppervlakte tussen deze twee bedrijfstypen veel geringer zijn en ook de verschillen tussen de extensieve bedrijven en de totale populaties zijn kleiner.

Binnen de gemengde bedrijven hebben de akkerbouw-graasdiercombinaties een behoorlijk lagere veedichtheid dan de overige gewas-veecombinaties (Tabel 21). Het verschil in veedichtheid tussen extensieve bedrijven en de totale populatie is bij de overige gewas-veecombinaties ook aanzienlijk groter. Daarnaast is de gemiddelde rustratio voor de akkerbouw-graasdiercombinaties iets hoger. De $\mathrm{N}$-norm is voor de extensieve bedrijven gemiddeld $32 \%$ lager dan voor de totale populatie, wat een behoorlijk verschil is. Met betrekking tot de $\mathrm{N}$-norm is tussen beide bedrijfstypen overigens maar weinig verschil. 
Tabel 21 Gemiddelde veedichtheid, rustratio en N-norm gemengde bedrijven.

\begin{tabular}{|c|c|c|c|c|}
\hline & $\begin{array}{l}\text { Extensieve } \\
\text { bedrijven }\end{array}$ & Alle bedrijven & $\begin{array}{c}\text { Verschil } \\
\text { (absoluut) }\end{array}$ & Verschil ( $\%)$ \\
\hline \multicolumn{5}{|l|}{ gem. GVE/ha } \\
\hline Overige gewas-veecombinaties & 0,67 & 1,57 & $-0,91$ & $-58 \%$ \\
\hline Totaal gemengd bedrijf & 0,59 & 1,12 & $-0,53$ & $-47 \%$ \\
\hline Akkerbouw-graasdiercombinaties & 0,58 & 0,48 & 0,11 & $+22 \%$ \\
\hline Overige gewas-veecombinaties & 0,49 & 0,44 & 0,04 & $+10 \%$ \\
\hline Totaal gemengd bedrijf & 0,55 & 0,46 & 0,09 & $+20 \%$ \\
\hline \multicolumn{5}{|l|}{ gem. N-norm } \\
\hline
\end{tabular}

(bron: GIAB 2016)

Tabel 22 Biologische productie en verbrede landbouw gemengde bedrijven.

\begin{tabular}{|c|c|c|c|c|}
\hline & \multicolumn{2}{|c|}{ Extensieve bedrijven } & \multicolumn{2}{|c|}{ Alle bedrijven } \\
\hline & Aantal & $\%$ & Aantal & $\%$ \\
\hline \multicolumn{5}{|l|}{ Biologische productie } \\
\hline Overige gewas-veecombinaties & 3 & $13 \%$ & 39 & $6 \%$ \\
\hline Totaal gemengd bedrijf & 5 & $7 \%$ & 53 & $4 \%$ \\
\hline Akkerbouw-graasdiercombinaties & 15 & $31 \%$ & 172 & $23 \%$ \\
\hline Overige gewas-veecombinaties & 10 & $42 \%$ & 179 & $27 \%$ \\
\hline Totaal gemengd bedrijf & 25 & $34 \%$ & 351 & $25 \%$ \\
\hline
\end{tabular}

(bron: GIAB 2016)

Hoewel de aantallen betrekkelijk gering zijn, zien we ook bij de gemengde bedrijven dat de extensieve bedrijven vaker biologisch en verbreed zijn (Tabel 22 ).

\subsection{Ruimtelijke analyse}

Voor de ruimtelijke analyse is het totaal van 73 gemengde bedrijven eigenlijk te gering voor een betrouwbaar beeld, vooral bij de uitsplitsing naar 66 deelgebieden. Het percentage extensieve gemengde bedrijven in de tabel hieronder is uitgedrukt als het aantal extensieve gemengde bedrijven/ totaal aantal gemengde bedrijven. Het percentage van het landbouwareaal dat in gebruik is bij de extensieve gemengde bedrijven is afgezet tegen het totale landbouwareaal. Kortom, 5\% van de gemengde bedrijven in Nederland is als extensief aan te duiden en deze bedrijven hebben $0,15 \%$ van het totale landbouwareaal in gebruik.

Uit Tabel 23 blijkt dat Zuid-Nederland de meeste extensieve gemengde bedrijven heeft en het areaalaandeel in gebruik bij de extensieve gemengde bedrijven is het hoogst in Zuid-Limburg, ZuidwestBrabant en het Zuidelijk veehouderijgebied. In een groot aantal deelgebieden zijn overigens überhaupt geen gemengde bedrijven, dus ook geen extensieve (Figuren 8 en 9). 
Tabel 23 Aantal en areaal extensieve gemengde bedrijven per deelgebied, absoluut en als aandeel.

\begin{tabular}{|c|c|c|c|c|}
\hline & $\begin{array}{c}\text { Aantal extensieve } \\
\text { gemengde } \\
\text { bedrijven }\end{array}$ & $\%$ & $\begin{array}{l}\text { Ha extensieve } \\
\text { gemengde } \\
\text { bedrijven }\end{array}$ & $\begin{array}{c}\% \text { van totale } \\
\text { landbouw areaal }\end{array}$ \\
\hline Bouwhoek en Hogeland & 0 & 0 & 0 & 0 \\
\hline Veenkoloniën en Oldambt & 8 & $22 \%$ & 230 & $0,25 \%$ \\
\hline IJsselmeerpolders & 0 & 0 & 0 & 0 \\
\hline Oost & 10 & $3 \%$ & 350 & $0,08 \%$ \\
\hline Oostelijk Veehouderijgebied & 9 & $5 \%$ & 330 & $0,12 \%$ \\
\hline Centraal Veehouderijgebied & 0 & 0 & 0 & 0 \\
\hline Waterland en Droogmakerijen & 0 & 0 & 0 & 0 \\
\hline Hollands/Utrechts weidegebied & 0 & 0 & 0 & 0 \\
\hline Zuidwest & 7 & $3 \%$ & 300 & $0,13 \%$ \\
\hline Zuidwestelijk akkerbouwgebied & 2 & $1 \%$ & 120 & $0,06 \%$ \\
\hline Zuidwest-Brabant & 5 & $8 \%$ & 180 & $0,53 \%$ \\
\hline Zuid & 43 & $\mathbf{8 \%}$ & 1.650 & $0,61 \%$ \\
\hline Zuidelijk veehouderijgebied & 28 & $6 \%$ & 1.030 & $0,43 \%$ \\
\hline Zuid-Limburg & 15 & $18 \%$ & 620 & $2,09 \%$ \\
\hline NL totaal & 73 & $5 \%$ & 2.860 & $0,15 \%$ \\
\hline
\end{tabular}

(bron: GIAB 2016)

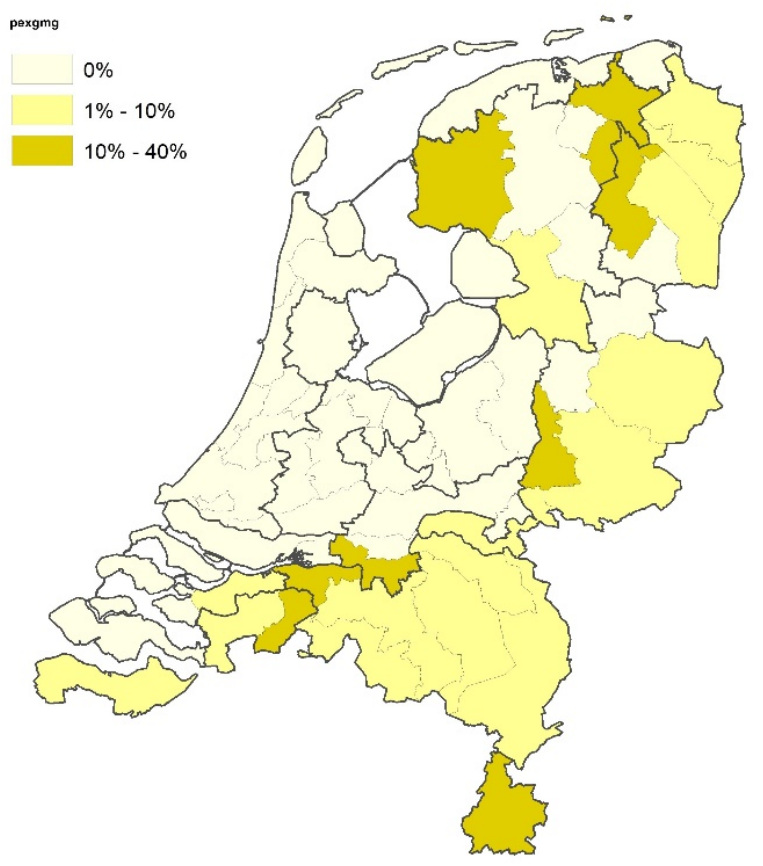

Figur 8 Aandeel extensieve gemengde bedrijven (bron: GIAB 2016).

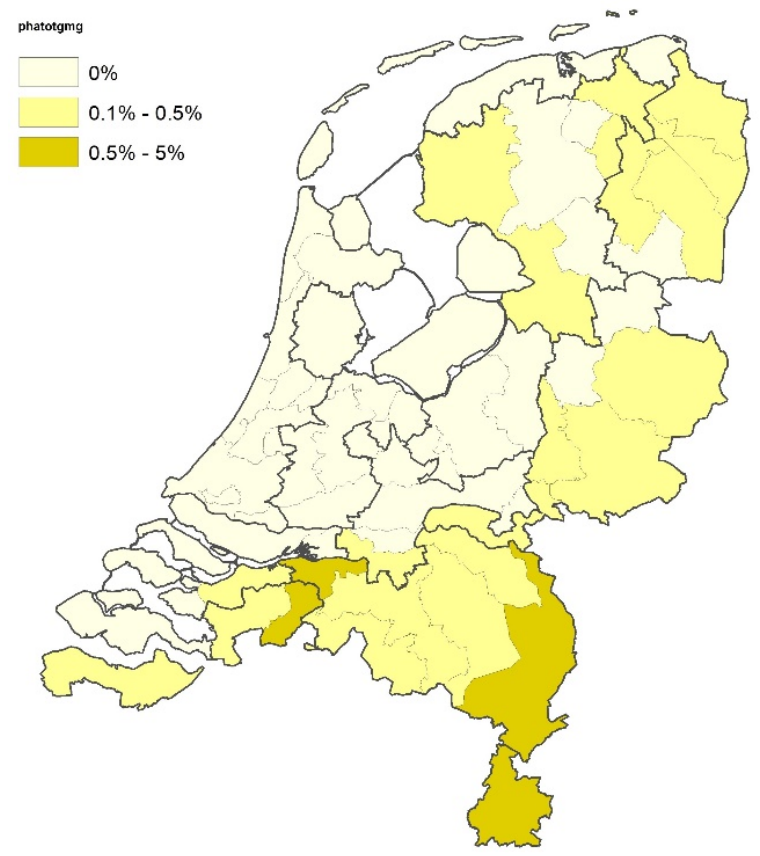

Figur 9 Aandeel van het totale landbouwareaal in gebruik bij extensieve gemengde bedrijven (bron: GIAB 2016). 


\section{Totaal extensieve bedrijven}

Door het aantal extensieve bedrijven en het areaal dat ze in gebruik hebben uit de vorige hoofdstukken te combineren, krijgen we een totaalbeeld. Onderstaande tabel geeft het totaal aan extensieve bedrijven weer en het areaal dat in gebruik is, gedifferentieerd naar de landbouwgebieden. Net als in de voorgaande hoofstukken is het aandeel extensieve bedrijven afgezet tegen het totaalaantal van de geselecteerde bedrijfstypen (van de graasdier-, akkerbouw- en gemengde bedrijven), terwijl het areaal-aandeel is afgezet tegen het totale landbouwareaal.

Tabel 24 Aantal en areaal extensieve landbouwbedrijven.

\begin{tabular}{|c|c|c|c|c|}
\hline & $\begin{array}{c}\text { Aantal extensieve } \\
\text { bedrijven }\end{array}$ & Aandeel ( $\%)$ & $\begin{array}{c}\text { Areaal extensieve } \\
\text { bedrijven } \\
\times 1.000 \text { ha }\end{array}$ & $\begin{array}{c}\text { Aandeel in totale } \\
\text { landbouwareaal } \\
(\%)\end{array}$ \\
\hline Bouwhoek en Hogeland & 210 & $16 \%$ & 8.9 & $10 \%$ \\
\hline Veenkoloniën en Oldambt & 470 & $18 \%$ & 27.2 & $14 \%$ \\
\hline IJsselmeerpolders & 60 & $4 \%$ & 2.8 & $3 \%$ \\
\hline Oost & 2.270 & $22 \%$ & 58.6 & $14 \%$ \\
\hline Oostelijk Veehouderijgebied & 1.510 & $21 \%$ & 32.2 & $12 \%$ \\
\hline Centraal Veehouderijgebied & 360 & $25 \%$ & 8.9 & $16 \%$ \\
\hline Waterland en Droogmakerijen & 210 & $36 \%$ & 7.8 & $26 \%$ \\
\hline Hollands/Utrechts weidegebied & 500 & $22 \%$ & 13.2 & $14 \%$ \\
\hline Zuidwest & 500 & $12 \%$ & 21.3 & $9 \%$ \\
\hline Zuidwestelijk akkerbouwgebied & 370 & $11 \%$ & 16.9 & $9 \%$ \\
\hline Zuidwest-Brabant & 130 & $18 \%$ & 4.4 & $13 \%$ \\
\hline Zuid & 1.040 & $17 \%$ & 33.0 & $12 \%$ \\
\hline Zuidelijk veehouderijgebied & 760 & $14 \%$ & 23.8 & $10 \%$ \\
\hline Zuid-Limburg & 280 & $36 \%$ & 9.2 & $31 \%$ \\
\hline NL totaal & 6.870 & $19 \%$ & 229.3 & $12 \%$ \\
\hline
\end{tabular}

(bron: GIAB 2016)

Op het niveau van de indeling naar de 5 landsdelen blijken Oost en West het hoogste aandeel extensieve landbouwbedrijven te hebben. Ook het areaal in gebruik bij de extensieve bedrijven is daar relatief het hoogst.

Bij de indeling naar 14 deelgebieden blijken Zuid-Limburg, Waterland en Droogmakerijen en Rivierengebied het hoogste aandeel extensieve landbouw te hebben, zowel in aantal bedrijven als in aandeel van het totale landbouwareaal. De deelgebieden met het laagste aandeel extensieve landbouw zijn IJsselmeerpolders, Zuidwestelijk akkerbouwgebied, Zuidelijk veehouderijgebied en Bouwhoek en Hogeland (figuren 8 en 9). Bij de indeling naar 66 landbouwgebieden vallen onder meer de Eilanden, de Oostelijke Veluwe en het Weidegebied van het Noorderveld op als gebieden met veel extensieve landbouw. 


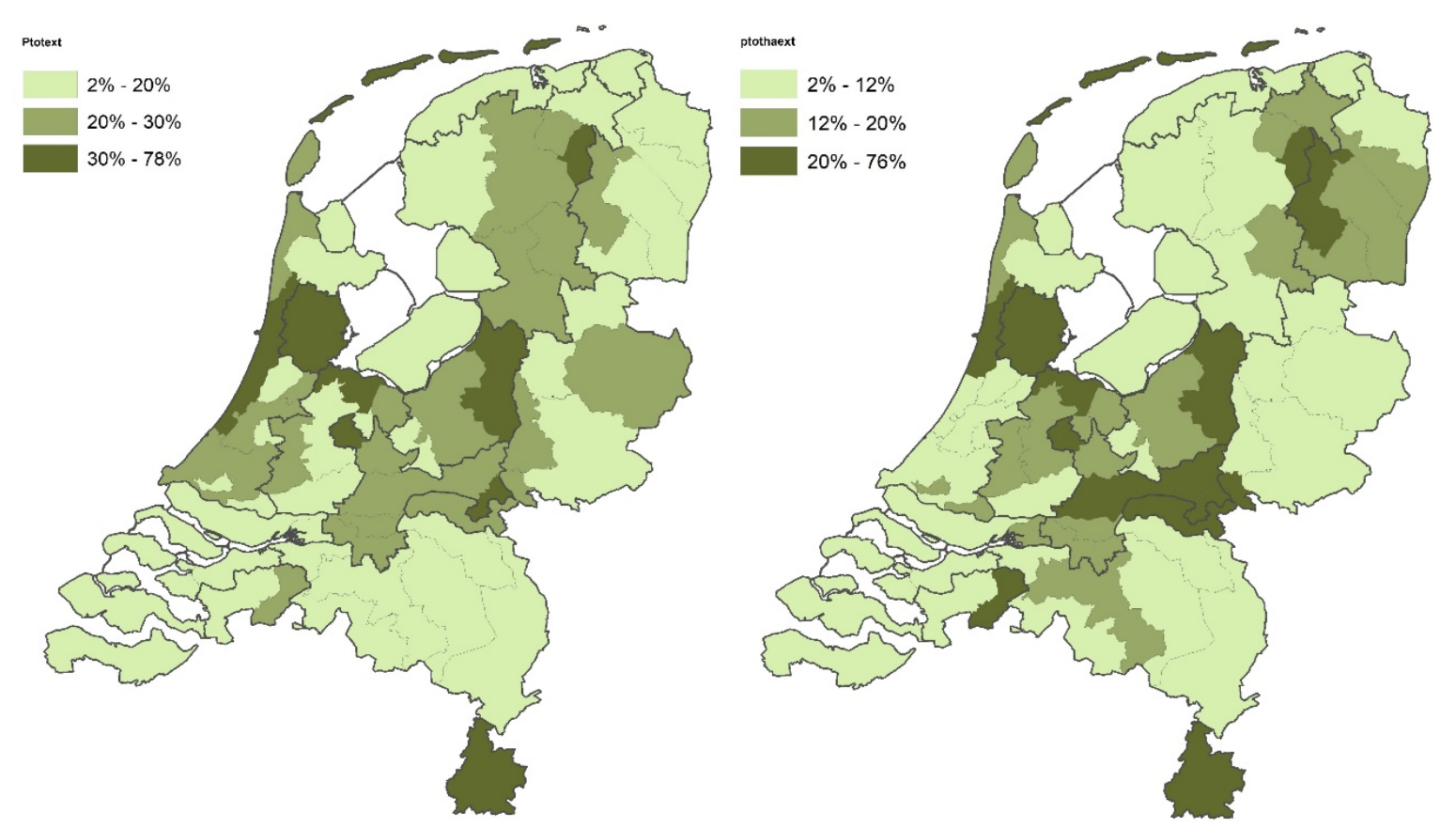

Figuur 10 Aandeel extensieve

Figuur 11 Aandeel van het landbouwareaal in landbouwbedrijven (bron: GIAB 2016). gebruik bij extensieve landbouwbedrijven (bron: GIAB 2016). 


\section{$7 \quad$ Discussie en conclusies}

In dit onderzoek hebben we een beeld geschetst van de extensieve landbouwsector in Nederland. De onderzoeksvragen kunnen we nu als volgt beantwoorden:

1. Welk aandeel hebben extensieve bedrijven in het totaal van de Nederlandse landbouw?

- Volgens de door ons gehanteerde definitie is $19 \%$ van de Nederlandse graasdier-, akkerbouwen gemengde bedrijven extensief. Dit betreft $25 \%$ van de graasdierbedrijven, $7 \%$ van de akkerbouwbedrijven en $5 \%$ van de gemengde bedrijven. Het relatief hoge aandeel extensieve graasdierbedrijven houdt verband met de overige rundvee- en schapenbedrijven. Deze zijn grotendeels extensief. Van de melkveebedrijven is $6 \%$ extensief.

- $12 \%$ van het Nederlandse landbouwareaal is in beheer bij extensieve bedrijven.

2. Wat is de verspreiding van extensieve bedrijven over Nederland?

- De Waddeneilanden, Waterland en Droogmakerijen, Rivierengebied, Centraal Veehouderijgebied en Hollands/Utrechts weidegebied komen naar voren als de deelgebieden met het hoogste aandeel van de landbouwgrond in gebruik bij extensieve graasdierbedrijven.

- Zuid-Limburg heeft verreweg het hoogste aandeel extensieve akkerbouw. Ook de deelgebieden Zuidwestelijk akkerbouwgebied en Zuidwest-Brabant hebben relatief veel extensieve akkerbouw, alsook de Veenkoloniën en Oldambt.

- Het areaal-aandeel in gebruik bij de extensieve gemengde bedrijven is het hoogst in ZuidLimburg, Zuidwest-Brabant en het Zuidelijk veehouderijgebied.

Het lage aandeel extensieve bedrijven in het totaal van de Nederlandse landbouw is het gevolg van de definities die in hoofdstuk 2 zijn gekozen. Deze wijken af van andere studies, die bijvoorbeeld het totaalaantal bedrijven in twee gelijke delen verdelen: het ene deel noemen ze intensief en het andere deel extensief. Wij wilden echter een definitie van extensief met ecologische betekenis: inzicht in het aandeel bedrijven waarvan verwacht kan worden dat ze gunstige condities scheppen voor biodiversiteit. Wij zijn voor deze studie op zoek gegaan naar een uniforme indicator voor effecten van de intensiteit van landbouwkundige ingrepen op de biodiversiteit op basis van GIAB-data en komen dan uit bij het stikstofgebruik op bedrijven. Van alle besproken opties heeft deze indicator vermoedelijk de sterkste verbinding met de biodiversiteit. De indicator heeft een nauwe relatie met ten minste twee van de vier drukfactoren vermesting, verzuring, verdroging en versnippering (PBL, 2014: tekstkader 3), namelijk vermesting en verzuring.

De lage percentages extensieve bedrijven zeggen dus vooral veel over de intensiteit van de Nederlandse landbouw.

De gebieden met een relatief hoog aandeel extensieve bedrijven zijn vaak gebieden waar gezien de fysieke omstandigheden hoogproductieve grondgebonden landbouw niet mogelijk is: het heuvelland van Zuid-Limburg, Waterland, de Waddeneilanden en de oostkant van de Veluwe. Van de natuurgraslanden wordt het grootste deel door extensieve graasdierbedrijven beheerd. Extensieve bedrijven zijn vaker biologisch en vaker verbreed. Ze doen onder meer vaker aan agrarisch natuur- en landschapsbeheer. Aan de ene kant vallen bedrijven met veel natuurgrond automatisch onder onze definitie van extensief. Aan de andere kant past beheer van (goedkope) natuurgrond bij de strategie en het verdienmodel van extensieve bedrijven. Biologisch en verbreding staan eveneens bekend als onderdelen van het verdienmodel van extensieve bedrijven. De biologische keten betaalt een hogere prijs voor het product. Verbreding biedt aanvullende inkomstenbronnen. Veel overige rundvee- en schapenbedrijven (ook de niet-extensieve) zijn deeltijd- of hobbybedrijven, waarbij het merendeel van het inkomen van buiten het bedrijf komt.

Vervolgonderzoek kan meer inzicht bieden in de opbouw van verdienmodellen van extensieve landbouwbedrijven. Want hoe kunnen deze bedrijven bestaan, terwijl hun geschatte verdiencapaciteit op basis van de opbrengst zoveel lager is dan die van intensievere bedrijven? Een analyse van de afstand van extensieve bedrijven tot natuurgebieden zou interessante inzichten kunnen opleveren, 
aangezien een 'buffer' van extensieve landbouw rondom natuurgebieden zou kunnen bijdragen aan natuurherstel (Folkert et al., 2020).

Ook zou aanvullend onderzoek gewenst zijn naar de in dit onderzoek gebruikte definities en grenzen en welke indicatoren nog beter kunnen aansluiten bij ecologische principes. Voor akkerbouwbedrijven geldt wellicht dat chemische gewasbeschermingsmiddelen een grotere impact hebben op de biodiversiteit dan de gekozen indicator van stikstofgebruiksnorm en rustgewas. We verwachten echter dat de gekozen indicator wel een goede proxy hiervoor is. Nader onderzoek zal kunnen uitwijzen of de hier gekozen indicator inderdaad de beste is om effecten van de intensiteit van landbouw op biodiversiteit te duiden. 


\section{Literatuur}

Allan, Eric et al. 2014. "Interannual variation in land-use intensity enhances grassland multidiversity." Proceedings of the National Academy of Sciences of the United States of America vol. 111,1 (2014): 308-13. doi:10.1073/pnas.1312213111

Bobbink, R. en M. Weijters, 2018. Verschil in effecten op natuur van gereduceerd versus geoxideerd stikstof. Tijdschrift Lucht, maart 2018 nummer 1.

CBS, 2019. Dierlijke mest en mineralen 2019. Den Haag: Centraal Bureau voor de Statistiek.

Daniëls, L. (red.), 2014. Biodiversiteit in de melkveehouderij. Investeren in de veerkracht en reduceren van risico's. Louis Bolk Instituut, Publicatienummer 2014-042 LbD, 55 pp.

Erisman, J.W., Eekeren, N. van, Doorn, A. van, Geertsema, W. \& Polman, N., 2017. Maatregelen Natuurinclusieve landbouw (No. 2821), Wageningen: Wageningen Environmental Research.

Eichhorn, K. en T. Van den Broek, 2013. Ecologie en beheer van kruidenrijke akkers op de zware en basische grondsoorten. Zeist: Eichhorn Ecologie \& Natuurmonumenten.

Eichhorn, K. en R. Ketelaar, 2011. Ecologie en beheer van kruidenrijke akkers op zandgronden. Zeist: Eichhorn Ecologie \& Natuurmonumenten.

EU, 2016. UITVOERINGSVERORDENING (EU) 2016/669 VAN DE COMMISSIE van 28 april 2016 tot wijziging van Uitvoeringsverordening (EU) nr. 808/2014 wat betreft de wijziging en de inhoud van plattelandsontwikkelingsprogramma's, de publiciteit over deze programma's en de omrekeningspercentages in grootvee-eenheden. Publicatieblad van de Europese Unie.

EZ, 2017. Regeling fosfaatreductieplan 2017. Staatscourant 2017, 9915.

Folkert, R., Bouwma, I., Kuindersma, W., van der Hoek, D-J., Gerritsen, A., Kunseler, E., Buijs, A., van Broekhoven, S., de Knegt, B., Aalbers, C., Kamphorst, D., van Doren, D., Klaassen, P., de Wit-de Vries, E., Roelofsen, H., Agricola, H., van Os, J., Frissel, J., Donders, J., ... van Dam, R. (2020). Lerende evaluatie van het Natuurpact 2020: Gezamenlijk de puzzel leggen voor natuur, economie en maatschappij: tweede rapportage. (PBL-publicatie; No. 3852). PBL Planbureau voor de Leefomgeving. https://edepot.wur.nl/525662

Kros, J., B.J. de Haan, R. Bobbink, J.A. van Jaarsveld, J.G.M. Roelofs \& W. de Vries, 2008. Effecten van ammoniak op de Nederlandse natuur. Wageningen, Alterra, Alterra-rapport 1698. 132blz; 45fig; 9 tab; 166ref.

KWIN-AGV, 2018. Kwantitatieve informatie voor de Akkerbouw en Vollegrondsgroenteteelt. Lelystad: WUR-PPO.

PBL, 2014. Biodiversiteit bekeken: hoe evalueert en verkent het PBL het natuurbeleid?, Den Haag: PBL

RVO, 2020a. Mestbeleid 2019-2021 Tabellen. Tabel 2 Stikstof landbouwgrond.

RVO, 2020b. Mestbeleid 2019-2021 Tabellen. Tabel 4 Diergebonden normen; Tabel 6 Stikstof en fosfaat per melkkoe.

Schippers, W., Bax, I. H. W., Gardenier, M., 2012. Ontwikkelen van kruidenrijk grasland: veldgids. Aardewerk Advies en Bureau Groenschrift.

Van Dijk, W., J. spruit, W. Runia \& W.C.A. van Geel, 2012. Verruiming vruchtwisseling in relatie tot mineralenbenutting, bodemkwaliteit en bedrijfseconomie op akkerbouwbedrijven. Lelystad. Praktijkonderzoek Plant en Omgeving, Publicatie nr. 527, 77 pp.

VROM, 2009 Besluit van 9 november 2009, houdende wijziging van het Besluit algemene regels voor inrichtingen milieubeheer (nieuwe activiteiten in en reparaties van het Besluit algemene regels voor inrichtingen milieubeheer); Staatsblad, 2009479.

van Dobben, H. F. 2020. Effecten van stikstofdepositie op de natuur en de rol van de kritische depositiewaarde. Tijdschrift Natuurbeschermingsrecht (NBR), 2020(2), 44-51. [39]. https://edepot.wur.nl/524747

Westerink, J. 2016. Making a difference: boundary management in spatial governance. Wageningen University. https://doi.org/10.18174/386527

Westerink, J., Plomp, M., Ottburg, F., Zanen, M., \& Schrijver, R. 2018. Boeren voor Natuur: de ultieme natuurinclusieve landbouw? Lessen van vier pilotbedrijven en relevantie voor beleid. (Wageningen Environmental Research rapport; No. 2858). Wageningen Environmental Research.

https://doi.org/10.18174/434934 


\section{Bijlage 1 Bedrijfstypen NSO-typering}

\section{P1 AKKERBOUWBEDRIJVEN}

\begin{tabular}{ll}
\hline Type $=1500$ & Graan-, oliezaad- en eiwitgewasbedrijven \\
\hline Type $=1601$ & Zetmeelaardappelbedrijven \\
\hline Type $=1602$ & Akkerbouwgroentebedrijven \\
\hline Type $=1603$ & Akkerbouwgroentebedrijven, vooral voedergewassen \\
\hline Type $=1604$ & Overige akkerbouwbedrijven
\end{tabular}

Type $=1604$

Overige akkerbouwbedrijven

\section{P2 TUINBOUWBEDRIJVEN}

\begin{tabular}{ll}
\hline Type $=2111$ & Glasgroentebedrijven \\
\hline Type $=2121$ & Snijbloemenbedrijven \\
\hline Type $=2122$ & Pot- en perkplantenbedrijven \\
\hline Type $=2131$ & Overige glastuinbouwbedrijven \\
\hline Type $=2210$ & Opengrondgroentebedrijven \\
\hline Type $=2221$ & Bloembollenbedrijven \\
\hline Type $=2310$ & Paddenstoelbedrijven \\
\hline Type $=2320$ & Boomkwekerijbedrijven \\
\hline Type $=2331$ & Overige tuinbouwbedrijven \\
\hline P3 BLIJVENDE TEELTBDRIJVEN
\end{tabular}

\section{P3 BLIJVENDE TEELTBEDRIJVEN}

\begin{tabular}{ll} 
Type $=3500$ & Wijngaardbedrijven \\
\hline Type $=3610$ & Fruitbedrijven \\
\hline Type $=3699$ & Overige blijvende teeltbedrijven
\end{tabular}

\section{P4 GRAASDIERBEDRIJVEN}

\begin{tabular}{ll}
\hline Type $=4500$ & Melkveebedrijven \\
\hline Type $=4611$ & Vleeskalverenbedrijven \\
\hline Type $=4612$ & Overige rundveebedrijven \\
\hline Type $=4810$ & Schapenbedrijven \\
\hline Type $=4830$ & Geitenbedrijven \\
\hline Type $=4841$ & Paard- en ponybedrijven \\
\hline Type $=4842$ & Graasdierbedrijven, vooral voedergewassen \\
\hline Type $=4843$ & Overige graasdierbedrijven \\
\hline P5 HOKDIERBEDIJVEN \\
\hline Type $=5111$ & Fokzeugenbedrijven \\
\hline Type $=5121$ & Vleesvarkensbedrijven \\
\hline Type $=5131$ & Overig varkensbedrijven \\
\hline Type $=5211$ & Leghennenbedrijven voor consumptie-eieren \\
\hline Type $=5221$ & Vleeskuikenbedrijven \\
\hline Type $=5231$ & Overige pluimveebedrijven \\
\hline Type $=5301$ & Overige hokdierbedrijven \\
\hline P6, P7 en P8 COMBINATIES \\
\hline Type $=6100$ & Gewassencombinaties \\
\hline Type $=7300$ & Veeteeltcombinaties, vooral graasdieren \\
\hline Type $=7400$ & Veeteeltcombinaties, vooral hokdieren \\
\hline Type $=8300$ & Akkerbouw-graasdiercombinaties \\
\hline Type $=8400$ & Overige gewas-veecombinaties \\
\hline
\end{tabular}

Referentie: https://edepot.wur.nl/423880 
Wageningen Environmental Research Postbus 47

6700 AA Wageningen

T 0317480700

www.wur.nl/environmental-research

Wageningen Environmental Research Rapport 3062

ISSN 1566-7197
De missie van Wageningen University \& Research is 'To explore the potential of nature to improve the quality of life'. Binnen Wageningen University \& Research bundelen Wageningen University en gespecialiseerde onderzoeksinstituten van Stichting Wageningen Research hun krachten om bij te dragen aan de oplossing van belangrijke vragen in het domein van gezonde voeding en leefomgeving. Met ongeveer 30 vestigingen, 6.500 medewerkers ( $5.500 \mathrm{fte}$ ) en 12.500 studenten behoort Wageningen University \& Research wereldwijd tot de aansprekende kennisinstellingen binnen haar domein. De integrale benadering van de vraagstukken en de samenwerking tussen verschillende disciplines vormen het hart van de unieke Wageningen aanpak. 


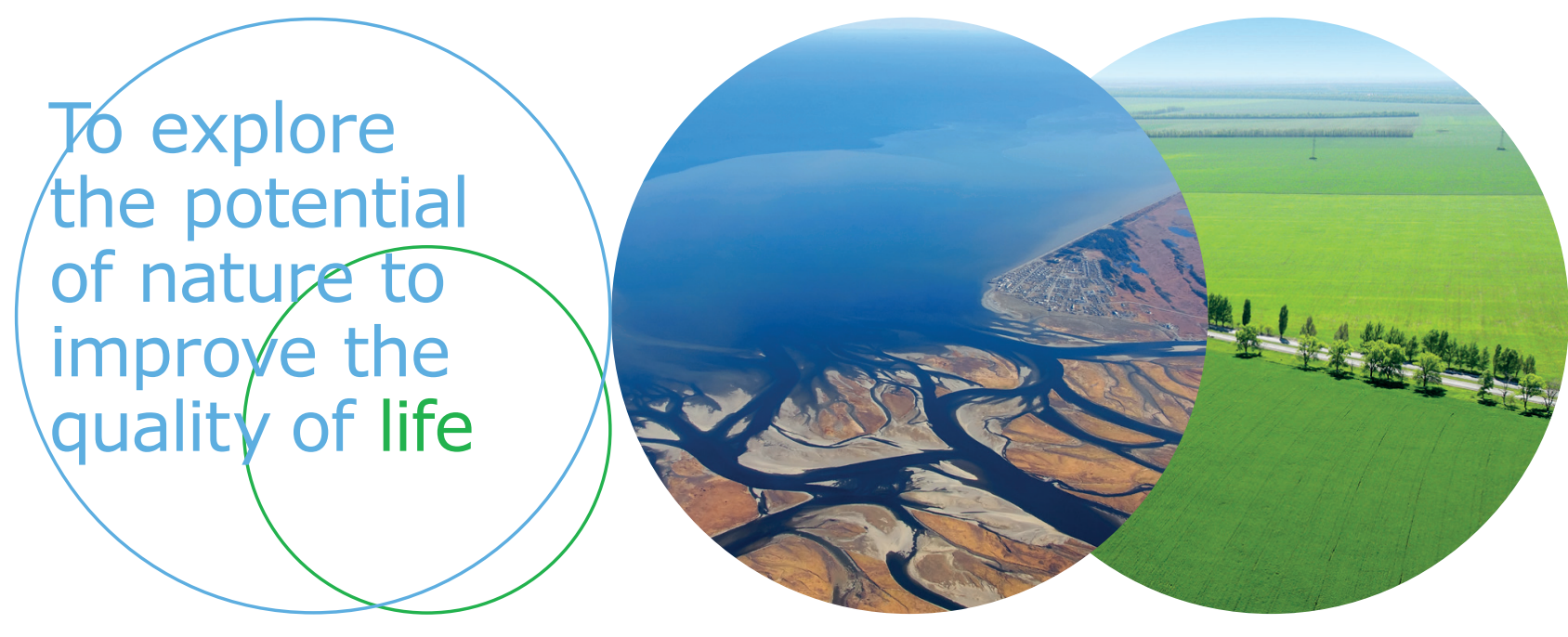

Wageningen Environmental Research Postbus 47

$6700 \mathrm{AB}$ Wageningen

T 317480700

www.wur.nl/environmental-research

Rapport 3062

ISSN 1566-7197
De missie van Wageningen University \& Research is 'To explore the potential of nature to improve the quality of life'. Binnen Wageningen University \& Research bundelen Wageningen University en gespecialiseerde onderzoeksinstituten van Stichting Wageningen Research hun krachten om bij te dragen aan de oplossing van belangrijke vragen in het domein van gezonde voeding en leefomgeving. Met ongeveer 30 vestigingen, 6.500 medewerkers ( $5.000 \mathrm{fte}$ ) en 12.500 studenten behoort Wageningen University \& Research wereldwijd tot de aansprekende kennisinstellingen binnen haar domein. De integrale benadering van de vraagstukken en de samenwerking tussen verschillende disciplines vormen het hart van de unieke Wageningen aanpak. 